\title{
On the investigation of COVID-19 lockdown influence on air pollution concentration: regional investigation over eighteen provinces in Iraq
}

\author{
Bassim Mohammed Hashim ${ }^{1}$ - Saadi K. Al-Naseri ${ }^{1}$ - Ali Al Maliki ${ }^{1}$ • Zulfaqar Sa'adi ${ }^{2}$. Anurag Malik ${ }^{3}$. \\ Zaher Mundher Yaseen ${ }^{4}$
}

Received: 11 January 2021 / Accepted: 1 April 2021 / Published online: 6 May 2021

(C) The Author(s), under exclusive licence to Springer-Verlag GmbH Germany, part of Springer Nature 2021

\begin{abstract}
At the end of 2019, a novel coronavirus COVID-19 emerged in Wuhan, China, and later spread throughout the world, including Iraq. To control the rapid dispersion of the virus, Iraq, like other countries, has imposed national lockdown measures, such as social distancing, restriction of automobile traffic, and industrial enterprises. This has led to reduced human activities and air pollutant emissions, which caused improvement in air quality. This study focused on the analysis of the impact of the six partial, total, and post-lockdown periods (1st partial lockdown from March 1 to16, 2020, 1st total lockdown from March 17 to April 21, 2nd partial lockdown from April 22 to May 23, 2nd total lockdown from May 24 to June 13, 3rd partial lockdown from June 14 to August 19, and end partial lockdown from August 20 to 31) on the average of daily $\mathrm{NO}_{2}, \mathrm{O}_{3}, \mathrm{PM}_{2.5}$, and $\mathrm{PM}_{10}$ concentrations, as well as air quality index (AQI) in 18 Iraqi provinces during these periods (from March 1st to August 31st, 2020). The analysis showed a decline in the average of daily $\mathrm{PM}_{2.5}, \mathrm{PM}_{10}$, and $\mathrm{NO}_{2}$ concentrations by $24 \%, 15 \%$, and $8 \%$, respectively from March 17 to April 21, 2020 (first phase of total lockdown) in comparison to the 1st phase of partial lockdown (March 1 to March 16, 2020). Furthermore, the $\mathrm{O}_{3}$ increased by $10 \%$ over the same period. The 2 nd phase of total lockdown, the 3 rd partial lockdown, and the post-lockdown periods witnessed declines in $\mathrm{PM}_{2.5}$ by $8 \%, 11 \%$, and $21 \%$, respectively, while the $\mathrm{PM}_{10}$ increases over the same period. Iraqi also witnessed improvement in the AQI by $8 \%$ during the 1 st phase of total lockdown compared to the 1st phase of partial lockdown. The level of air pollutants in Iraq declined significantly during the six lockdown periods as a result of reduced human activities. This study gives confidence that when strict measures are implemented, air quality can improve.
\end{abstract}

Keywords Air pollution · Iraqi provinces · COVID-19 $\cdot$ Lockdown $\cdot$ Air quality index

Responsible Editor: Lotfi Aleya

Zaher Mundher Yaseen

yaseen@alayen.edu.iq

Bassim Mohammed Hashim

bassim_saa22@yahoo.com

Saadi K. Al-Naseri

saadikadhum@gmail.com

Ali Al Maliki

alyay004@mymail.unisa.edu.au

Zulfaqar Sa'adi

zulfaqar@utm.my

Anurag Malik

amalik19@pau.edu
1 Environment and water Directorate, Ministry of Science and Technology, Baghdad, Iraq

2 Centre for Environmental Sustainability and Water Security (IPASA), School of Civil Engineering, Faculty of Engineering, Universiti Teknologi Malaysia, 81310 UTM Sekudai, Johor, Malaysia

3 Punjab Agricultural University, Regional Research Station, Bathinda, Punjab, India

4 New era and development in civil engineering research group, Scientific Research Center, Al-Ayen University, Thi-Qar, 64001, Iraq 


\section{Introduction}

On December 31, 2019, a novel coronavirus was reported in the Wuhan region of Central Hubei Province, China (Shi et al. 2020). Subsequently, the World Health Organization (WHO) named the novel coronavirus as COVID-19 and classified it as a novel group of coronaviridae that is also called severe acute respiratory syndrome coronavirus 2 (SARS-CoV-2) (Hassan et al. 2020) owing to its close similarity to the earlier virus that caused the 2002-2003 epidemic called severe acute respiratory syndrome (SARS) (Xu et al. 2020a). More than 8000 people from various countries were infected with SARS-CoV while more than 774 persons died. In 2012, another coronavirus called MERS coronavirus (MERS$\mathrm{CoV}$ ) emerged in the Middle East, infecting about 2494 with a disease called "Middle East respiratory syndrome" whereas about 860 persons died from it (Munster et al. 2020). It was initially thought that COVID-19 has a zoonotic origin ( $\mathrm{Lu}$ et al. 2020) as the earlier two coronavirus-related diseases (MERS and SARS) originated from human interaction with animals. Since the emergence of COVID-19 in Wuhan, China, it has spread to almost all the countries of the world ( $\mathrm{Li}$ et al. 2020), causing different degrees of respiratory illness. Owing to the rate of its spread throughout the world, it was subsequently declared a pandemic by the WHO on January 30 , 2020 (Lu et al. 2020). Since then, it has been reported in almost all regions of the world (WHO 2020). The pandemic has been felt in at least 190 countries; as of August 31,2020 , more than $25,154,771$ infections have been confirmed while 844,605 deaths were reported (https:// covid19.who.int/).

According to the WHO, COVID-19 is contracted via direct contact with a person that has been infected by the virus, or through touching surfaces that carry the virus. One major source of worry regarding this virus is that it presents similar symptoms as other mild viral diseases, including dry cough, flu, fever, and sore throat (Huang et al. 2020). Some measures have been put in place to reduce the spread of the virus; these include personal hygiene, maintaining proper social distance, avoiding large gatherings, and staying home when there is no need of going outside to reduce the risk of contracting the virus (Bherwani et al. 2020; Gautam and Hens 2020). With these measures in place, human activities have been greatly impacted and both local and global economies have been adversely impacted (Chu et al. 2020; Long and Feng 2020; Sharifi and Khavarian-Garmsir 2020).

Iraq confirmed the COVID-19 index case in Najaf, southern Baghdad on the 24th day of February 2020 (WHO, situation report-36). In a bid to ensure appropriate control of the virus, series of lockdown measures (partial and total) were announced by the Iraqi government on March 1, 2020; this included the closing of schools, airports, railways, and restriction of all forms of movement between provinces (Jebril 2020). As of August 31, 2020, Iraqi has already confirmed more than 234,934 cases of COVID-19 and more than 7042 deaths (Ministry of Health 2020).

Being a pandemic, the lockdown measures that were announced to prevent the spread of the pandemic $(\mathrm{Wu}$ and McGoogan 2020) have negatively affected human activities in the form of restricted vehicle use, public transportation, and other economic activities (Gautam and Trivedi 2020; Pata 2020; Bashir et al. 2020; Shehzad et al. 2020). But one good aspect of the restrictions is that air quality has greatly improved during the lockdown periods owing to reduced human activities and low emission of air pollutants. One major problem of the twenty-first century has been the continuous deterioration of air quality due to different kinds of human activities (Motesaddi et al. 2017; He et al. 2020). Air pollution remains a major public health threat globally (Begum et al. 2013; Tung et al. 2014; Tusher et al. 2019) and being that more than $55 \%$ of the global population lives in the industrialized areas (United Nations 2019), air pollution due to various industrial activities remains a global threat (Lelieveld et al. 2015). In 2016, more than 4.2 million people died prematurely due to pollution-related illnesses globally (WHO 2019).

Air pollution is defined as the suspension of particulate materials $\left(<2.5\right.$ or $10 \mathrm{~mm} ; \mathrm{PM}_{2.5}$ and $\left.\mathrm{PM}_{10}\right)$ in the air; there is also increased concentrations of different gases in the air, such as nitrogen dioxide $\left(\mathrm{NO}_{2}\right)$, volatile organic compounds (VOCs), ozone $\left(\mathrm{O}_{3}\right)$, and carbon monoxide (CO) released from vehicle exhaust pipes and industrial activities (Cohen et al. 2017). $\mathrm{NO}_{2}$ is one of the highly reactive gases identified as nitrogen oxides (NOx); it irritates the human respiratory system and can endanger the ecosystem via the formation of acid rain and nitric acid (EPA 2020a). Particulate materials (PM) are the major component of air pollutants (Burke 2020) as they are a mixture of different materials suspended in the air. They are a threat to human health as they enter the bloodstream and the human lungs. Most cases of poor visibility are associated with a high concentration of $\mathrm{PM}_{2.5}$ in the air (EPA 2020b). Owing to the effect of ground-level $\mathrm{O}_{3}$ on human health, it is considered the most harmful air pollutants (Sicard et al. 2016, 2019; Nuvolone et al. 2017).

The Iraqi economy relies mainly on the energy sector as it is the main source of foreign exchange. Fossil fuels are mainly used for energy production in Iraq and due to population growth, the demand for local consumption has increased tremendously (Hashim et al. 
2020b). The activities involved in gas flaring, oil refining, and generation of electricity, as well as the increase in people movement, have all contributed to air contamination in Iraq (IEA 2012). Despite the abundance of fossil fuel for energy production in Iraq, the national electric power grid has not lived up to expectation and people have resorted to various sizes of power generators to meet their energy needs; these are contributors to the deteriorating quality of air in Iraq, especially in the big cities like Basra and Baghdad (Ministry of Environment 2016). As Iraq is notorious for various high-density traffic areas, high levels of emission of different pollutants are expected and the impact on the environment and the economy is expected to be on the increase (Jassim et al. 2014).

Most studies in many countries have recently focused on changes in air quality (Das et al. 2020; Sulaymon et al. 2021; Vulichi et al. 2021) and water quality (Khan et al. 2021) during this era of COVID-19. There are no studies so far that have dealt with studying air pollution during the Covid-19 pandemic at the level of Iraq. As a result of this knowledge gap, few studies have addressed the issue of air pollution during the pandemic. For instance, the effect of COVID-19-related lockdown measures on the levels of air pollutants in Baghdad, Iraq, has been studied by Hashim et al. (2020a) from February 24 to July 24, 2020. The study focused on the analysis of the daily $\mathrm{PM}_{2.5}, \mathrm{PM}_{10}, \mathrm{NO}_{2}$, and $\mathrm{O}_{3}$ concentrations pre-and during the national lockdown periods in Baghdad. During these periods, Baghdad witnessed decreases in $\mathrm{NO}_{2}, \mathrm{PM}_{2.5}$, and $\mathrm{PM}_{10}$ levels by $6 \%, 8 \%$, and $15 \%$, respectively from the 1st March to 21st April 2020 (covering the 1st phase of partial and complete lockdown) in comparison to the prelockdown period. A $13 \%$ increase was also observed in $\mathrm{O}_{3}$ concentration over the same period. From 14th June to 24th July (2nd phase of partial lockdown), there was a $20 \%$ decrease in $\mathrm{NO}_{2}$ level and $2.5 \%$ decrease in $\mathrm{PM}_{2.5}$ level while $\mathrm{O}_{3}$ level decreased by $52 \%$ and $\mathrm{PM}_{10}$ level increased by $56 \%$ within the same period. Baghdad also witnessed a $13 \%$ improvement in air quality index (AQI) from March 1 to April 21, 2020 (1st partial lockdown) in comparison to the pre-lockdown period.

The decline in the levels of air pollution as a result of the measures to contain the novel coronavirus has been the focus of many studies, especially in China where the virus emerged in 2019 (Shakil et al. 2020). For instance, the study by $\mathrm{Xu}$ et al. (2020b) reported a $30 \%$ and $40 \%$ decline in $\mathrm{PM}_{2.5}$, and $\mathrm{PM}_{10}$ concentration while $\mathrm{SO}_{2}, \mathrm{NO}_{2}$, and $\mathrm{CO}$ concentrations decreased by $61 \%, 33 \%$, and $28 \%$, respectively over three Central China cities in February 2020. Another study by Bao and Zhang (2020) reported an average decline of $7.8 \%$ in AQI over 44 northern China cities. In the same manner, a significant reduction in air pollutant levels $\left(\mathrm{PM}_{2.5}, \mathrm{PM}_{10}, \mathrm{CO}, \mathrm{SO}_{2}\right.$, and $\left.\mathrm{NO}_{2}\right)$ have been reported across different regions of the world during the period of the COVID-19 pandemic (Wang and $\mathrm{Su} 2020$; Collivignarelli et al. 2020; Dantas et al. 2020; Kerimray et al. 2020; Nakada and Urban 2020; Cárcel-Carrasco et al. 2021; Bhat et al. 2021).

In Iraq, the changes in daily average $\mathrm{O}_{3}, \mathrm{NO}_{2}, \mathrm{PM}_{2.5}$, $\mathrm{PM}_{10}$, and AQI were calculated over the six phases of partial and total lockdown (March 1 to August 20, 2020), as well as during the post-lockdown period (August 21 to 31, 2020). The study mainly aimed at evaluating the differences in the average daily concentrations (in $\mu \mathrm{g} / \mathrm{m}^{3}$ ) and relative variation (in $\%$ ) between the six periods of partial, total, and post-lockdowns. Also, the daily concentrations of different air pollutants and AQI in 18 Iraqi provinces. In this study, the focus is on the impacts of the COVID-19-related lockdown periods on air quality in all provinces in Iraqi; it should be noted that Baghdad and Basra are among the places with high levels of air pollution in the Middle East due to high human activities (Ministry of Health and Environment 2016).

\section{Material and methods}

\section{Study area}

Being a Middle Eastern country, Iraq is located approximately on $33^{\circ} 00^{\prime} \mathrm{N}$ latitude (between $29^{\circ} 02^{\prime} \mathrm{N}$ and $37^{\circ}$ $23^{\prime} \mathrm{N}$ ) and $44^{\circ} 00^{\prime} \mathrm{E}$ longitude (between $38^{\circ} 47^{\prime} \mathrm{E}$ and $48^{\circ} 35^{\prime} \mathrm{E}$ ). Iraq has a total area of $438,317 \mathrm{~km}^{2}$, with the residents mostly settled along the Tigris and Euphrates Rivers in the eastern, northern, and central regions of the country. Due to harsh weather and lack of basic facilities, most of the western and southern regions are partly inhabited; hence, both regions are mostly desert areas (Chabuk et al. 2020). The middle and southern regions of Iraq have varying climates, ranging from continental and subtropical to arid and semi-arid, while the mountainous northern and north-eastern regions have a Mediterranean climate, as shown in Fig. 1 (Al-Ansari et al. 2018; Salman et al. 2020). Rainfall is mainly experienced during December to February but can extend to 6 months (November-April) in the northern and northeastern regions. The average winter temperature is about $16{ }^{\circ} \mathrm{C}$, with the day temperature dropping to about $2{ }^{\circ} \mathrm{C}$ while the night temperature reaches sub-zero. During the summer periods, the weather is extremely hot, with day temperature reaching over $43{ }^{\circ} \mathrm{C}$ in July and August and drops to around $26{ }^{\circ} \mathrm{C}$ at night (The World Bank 2006; Frenken 2009). 
Fig. 1 Topographic and climatic zones of Iraq (Salman et al. 2020)

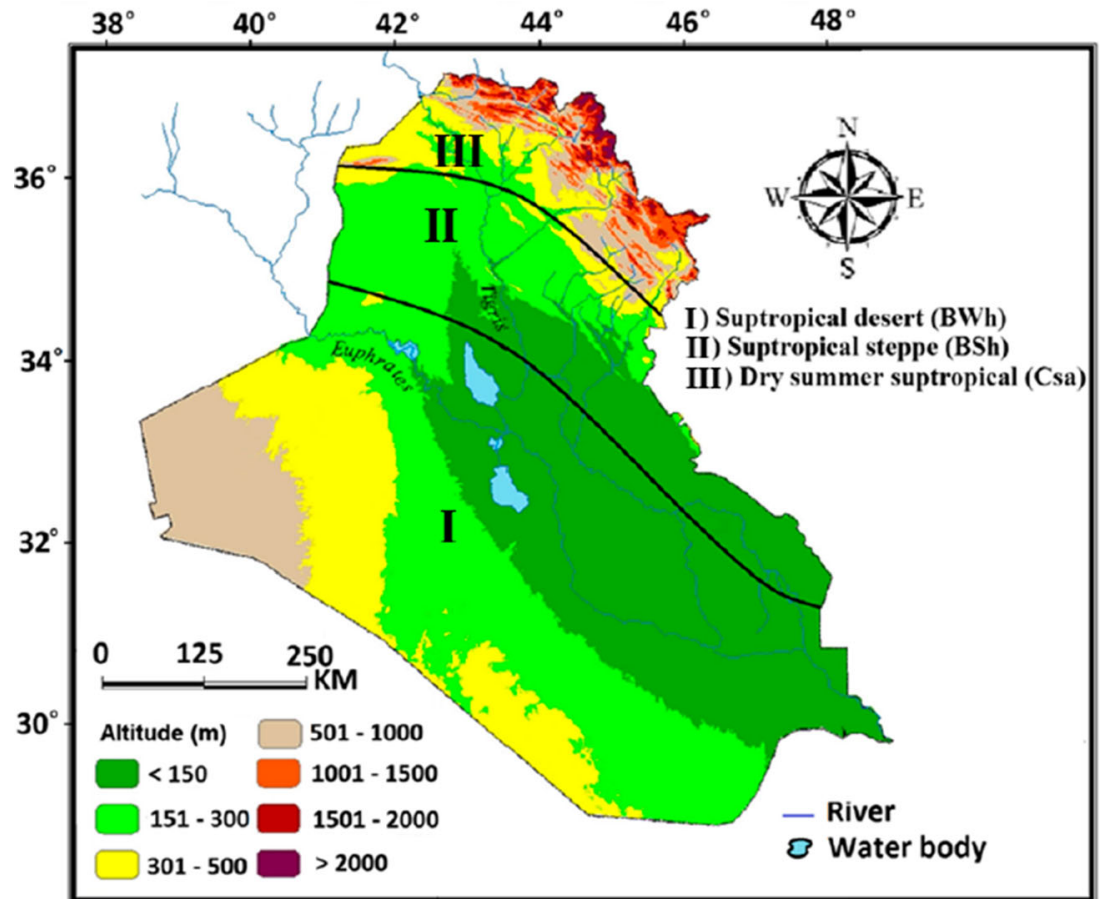

\section{Data sources}

The research methodology is based on studying the daily concentrations of four air pollutants in the provinces of Iraq during the period of partial and total lockdown. Because data on these pollutants were not available from the official Iraqi authorities during or before the aforementioned period, due to technical and administrative problems. The air pollution data used in this study was captured from an online monitoring system (https://air. plumelabs.com/en/) that captures and analyses the quality of air over a region (World Air Map 2020). The daily $\mathrm{NO}_{2}, \mathrm{O}_{3}, \mathrm{PM}_{2.5}$, and $\mathrm{PM}_{10}$ levels were measured for all the 18 Iraqi provinces during and after the lockdown periods (March 1 to August 31, 2020); the AQI was also measured for the same period. There were no records of the $\mathrm{NO}_{2}, \mathrm{O}_{3}, \mathrm{PM}_{2.5}$, and $\mathrm{PM}_{10}$ concentrations for the previous years. On the other hand, the mentioned pollutants are the most air pollutants in Iraq, due to the spread of power generation and the oil industry in many places in Iraq, in addition to the increasing number of vehicles (Ministry of Environment 2016). The partial, total, and post-lockdown periods in Iraq (March 1 to August 31, 2020) considered in this study are shown in Table 1.

\section{AQI calculations}

The AQI of the provinces during the considered period of study was calculated to understand the overall changes in air quality. To calculate the AQI values, the concentrations of a minimum of three air pollutants (such as $\mathrm{NO}_{2}, \mathrm{O}_{3}, \mathrm{PM}_{2.5}$, and $\mathrm{PM}_{10}$ ) must be available as these concentrations are to be transformed into numbers on a scale of $0-500$. Equation 1 is used for the sub-index AQI ( $\left.\mathrm{AQI}_{i}\right)$ calculation for each pollutant (i).

$$
\mathrm{AQI}_{i}=\frac{I N_{H I}-I N_{L O}}{B_{H I}-B_{L O}} \times\left(C_{I}-B_{L O}\right)+I N_{L O}
$$

where $C_{I}$ is the air concentration of pollutant " $i$ "; $I N_{H I}$ and $I N_{L O}$ are the related AQI values; and $B_{H I}$ and $B_{L O}$ are the breakpoint pollutant concentrations (greater than and less than $C_{I}$ ). The overall AQI represents the max. $\mathrm{AQI}_{i}$ while the related pollutant is the leading pollutant. AQI values can be

Table 1 Partial, total, and post-lockdown periods in Iraqi provinces from March 1 to August 31, 2020, for the current study

\begin{tabular}{ll}
\hline Situation & Partial and total lockdown periods \\
\hline During 1st partial lockdown & March 1 to 16, 2020 \\
During 1st total lockdown & March 17 to April 21, 2020 \\
During 2nd partial lockdown & April 22 to May 23, 2020 \\
During 2nd total lockdown & May 24 to June 13, 2020 \\
During 3rd partial lockdown & June 14 to August 19, 2020 \\
End partial lockdown & August 20 to 31, 2020 \\
\hline
\end{tabular}


classified into 6 categories as follows: good $(0-50)$, satisfactory $(51-100)$, moderate $(101-200)$, poor $(201-300)$, very poor (301-400), and severe (401-500) (Sharma et al. 2020).

\section{Results and discussion}

\section{Assessment of air pollution levels during COVID-19}

Various human activities were restricted during the lockdown measures to contain the spread of COVID19. As a result, there were significant declines in energy demand and consumption. These declines in energy demand impacted the transportation sector severely and consequently reduced the rate of air pollutant emission; hence, air quality was significantly improved during these periods of lockdown.

\section{$\mathrm{NO}_{2}$ concentration}

The observed daily average concentrations of $\mathrm{NO}_{2}(\mu \mathrm{g} /$ $\mathrm{m}^{3}$ ) in the Iraqi provinces during and after the lockdown periods (March 1 to August 31, 2020) are shown in Fig. 2a. From March 1 to March 16 (the 1st partial lockdown period), the daily average concentration of $\mathrm{NO}_{2}$ significantly reduced in Iraq as transportation activities were significantly restricted due to the implementation of the rules on social distancing; on average, the $\mathrm{NO}_{2}$ concentration was $42 \mu \mathrm{g} / \mathrm{m}^{3}$ during this period. The 1st period of total lockdown (17th March 220 to 21st April 2020) witnessed a decline in daily $\mathrm{NO}_{2}$ concentration, reaching $39 \mu \mathrm{g} / \mathrm{m}^{3}$. To ease the restriction measures on citizens, a 2nd partial lockdown period was imposed from April 22 to May 23 and during this period, there was a significant increase in the average daily $\mathrm{NO}_{2}$ concentrations in Iraq, reaching $42 \mu \mathrm{g} / \mathrm{m}^{3}$. As the number of confirmed COVID-19 cases increased in Iraq, the 2nd phase of total lockdown was implemented from 24th May 2020 to 13th June 2020, and during this period, the daily average $\mathrm{NO}_{2}$ concentrations reduced to $38 \mu \mathrm{g} / \mathrm{m}^{3}$. However, the relaxation of the 2nd total lockdown and introduction of the 3rd partial lockdown phase (from June 14 to August 20, 2020) brought about an increase in the daily average $\mathrm{NO}_{2}$ concentration in Iraq, reaching $40 \mu \mathrm{g} / \mathrm{m}^{3}$. Relaxation of the 3rd partial lockdown from August 21, 2020, caused an increase in the average daily $\mathrm{NO}_{2}$ concentration as it reached $46 \mu \mathrm{g} / \mathrm{m}^{3}$ throughout Iraq. The daily average concentration of $\mathrm{NO}_{2}$ in Iraq during the postlockdown phases in Iraqi provinces is presented in Fig. $2 \mathrm{a}$; observably, the values were still within the limit recommended by WHO which is $200 \mu \mathrm{g} / \mathrm{m}^{3}$ (World Health Organization 2006). Figure $2 b$ shows the spatial distribution of the average daily concentrations of $\mathrm{NO}_{2}$ for Iraqi provinces from March 1 to August 31, 2020. The highest levels of $\mathrm{NO}_{2}$ were observed in Baghdad and Babylon during the study periods. The average daily $\mathrm{NO}_{2}$ concentrations for all provinces of Iraq are provided as supplementary material (Fig. 3).

\section{Concentration of $\mathrm{O}_{3}$}

The average daily concentration of $\mathrm{O}_{3}$ during and after the lockdown periods (March 1 to August 31, 2020) is shown in Fig. 4a. The 1st phase of partial lockdown (March 1 to 16,2020 ), witnessed an average daily $\mathrm{O}_{3}$ concentration of $40 \mu \mathrm{g} / \mathrm{m}^{3}$. The announcement of the 1 st total lockdown phase (March 17 to April 21, 2020) brought about an increase in the average daily concentration of $\mathrm{O}_{3}$, reaching $44 \mu \mathrm{g} / \mathrm{m}^{3}$. The 2nd partial lockdown period (April 22 to May 23, 2020) was graced with a slight decrease in daily $\mathrm{O}_{3}$ concentrations, reaching $43 \mu \mathrm{g} / \mathrm{m}^{3}$. The reintroduction of a 2 nd total lockdown period in Iraq (May 24 to June 13, 2020) brought about the highest increase in the daily average concentration of $\mathrm{O}_{3}$ as it reached $58 \mu \mathrm{g} / \mathrm{m}^{3}$ due to low $\mathrm{NO}_{2}$ concentration and high temperatures. The observed daily average concentration of $\mathrm{O}_{3}$ in Iraq decreased to $57 \mu \mathrm{g} / \mathrm{m}^{3}$ from June 14 to August 20, 2020 (3rd partial lockdown). From August 21 to 31, 2020 (the end of the 3rd partial lockdown in Iraq), the average daily $\mathrm{O}_{3}$ concentrations were reduced to $49 \mu \mathrm{g} /$ $\mathrm{m}^{3}$. The spatial distribution of the average daily $\mathrm{O}_{3}$ concentrations for Iraqi provinces from March 1 to August 31, 2020, was shown in Fig. 4b. The highest levels of $\mathrm{O}_{3}$ were recorded in the Wassit, Missan, and Thi-Qar provinces during the study periods. A supplementary file illustrating the average of the daily $\mathrm{O}_{3}$ concentrations for all the provinces of Iraq is provided in Fig. 5.

\section{PM 2.5 concentration}

The daily average concentrations of $\mathrm{PM}_{2.5}\left(\mu \mathrm{g} / \mathrm{m}^{3}\right)$ in Iraqi provinces are shown in Fig. 6a (from March 1 to August 31, 2020). Observably, the average daily $\mathrm{PM}_{2.5}$ concentration in Iraq was $38 \mu \mathrm{g} / \mathrm{m}^{3}$ from March 1 to 16 , 2020 (1st partial lockdown). From March 17 to April 21, 2020 (1st period of total lockdown), the daily average $\mathrm{PM}_{2.5}$ concentration significantly reduced to $29 \mu \mathrm{g} / \mathrm{m}^{3}$ but from 22nd April to 23rd May 2020 (2nd partial lockdown), there was an increase in the $\mathrm{PM}_{2.5}$ concentrations, reaching $38 \mu \mathrm{g} / \mathrm{m}^{3}$ following the partial reopening of the economy. The 2nd total lockdown period (May 25 to June 13,2020 ) saw a slight decrease in the average $\mathrm{PM}_{2.5}$ concentration to $35 \mu \mathrm{g} / \mathrm{m}^{3}$. There were variations in the average daily concentration of $\mathrm{PM}_{2.5}$ during the $3 \mathrm{rd}$ partial lockdown (June 14 to August 20, 2020) as the 
Fig. 2 a The average of daily $\mathrm{NO}_{2}$ concentrations $\left(\mu \mathrm{g} / \mathrm{m}^{3}\right)$ in provinces of Iraq, during and post the lockdown from the 1 st of March to August 31, 2020. b The spatial distribution of the averages of daily $\mathrm{NO}_{2}$ concentrations for

18 Iraqi provinces from the 1 st of March to August 31, 2020 (a)

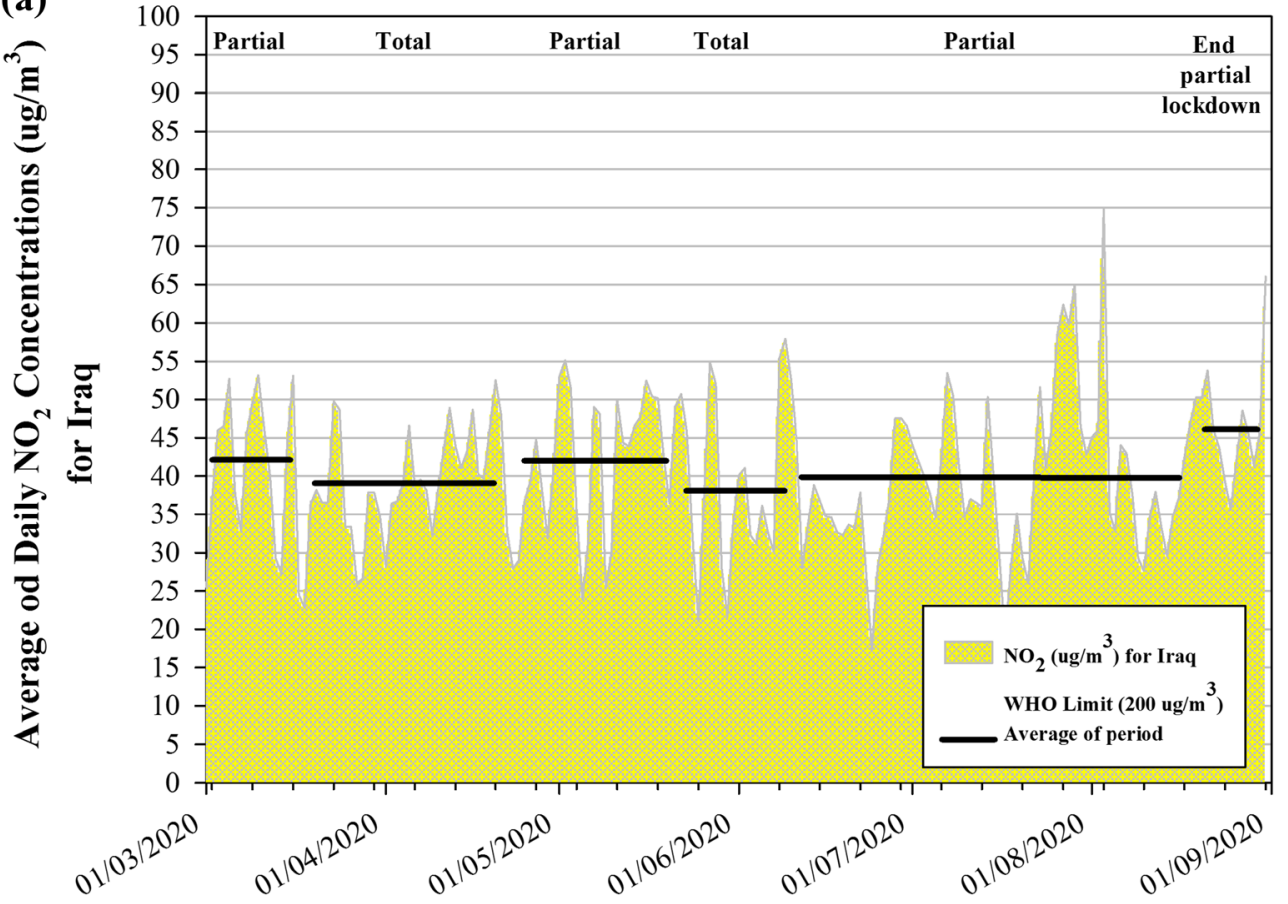

\section{Time}

(b)

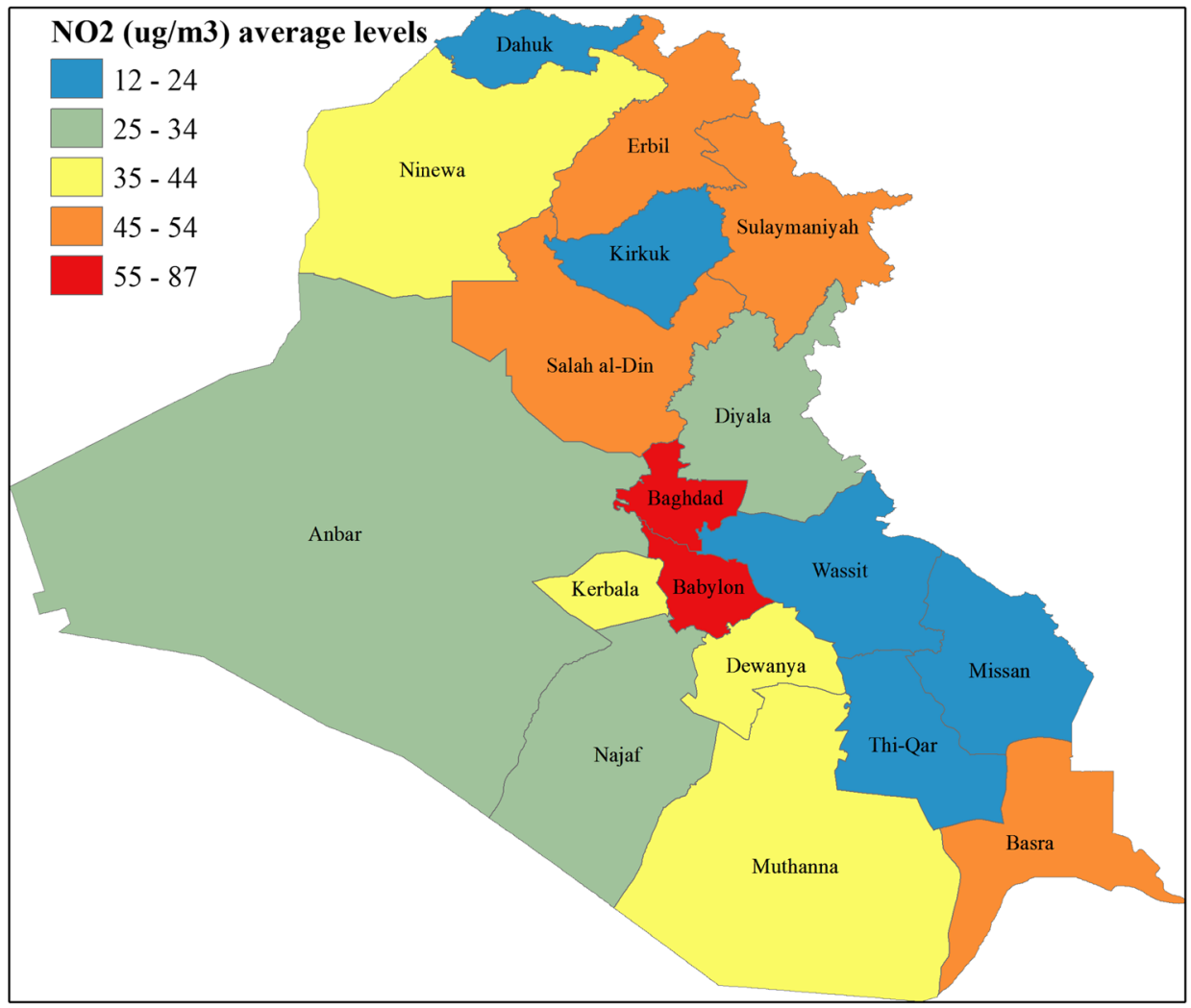


Fig. 3 The average of daily $\mathrm{NO}_{2}$ concentrations for provinces of Iraq from March 1 to August 31, 2020

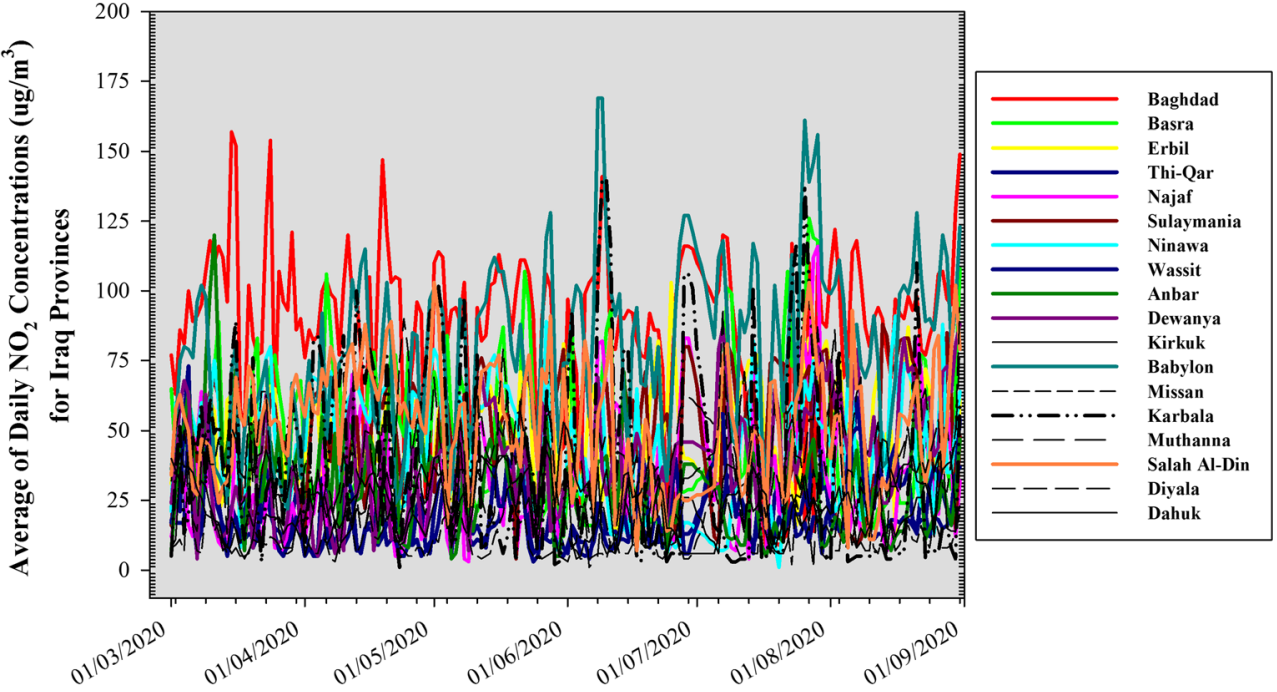

Time average value was around $34 \mu \mathrm{g} / \mathrm{m}^{3}$. Upon lifting of restriction at the end of the 3 rd partial lockdown (from August 21 to 31, 2020), Iraq witnessed a clear increase in the average daily $\mathrm{PM}_{2.5}$ concentrations as it reached 30 $\mu \mathrm{g} / \mathrm{m}^{3}$ throughout the country. Although the observed daily $\mathrm{PM}_{2.5}$ concentration in the Iraqi provinces exceeded the recommended WHO limits $\left(25 \mu \mathrm{g} / \mathrm{m}^{3}\right.$ ) (World Health Organization 2006), especially during the 1 st total lockdown period, however, most of the observed excesses in $\mathrm{PM}_{2.5}$ concentrations during the study period were only during May and June as a result of drought and extreme temperatures in different Iraqi cities. The spatial distribution of the averages of daily $\mathrm{PM}_{2.5}$ concentrations for Iraqi provinces from March 1 to August 31, 2020, is shown in Fig. 6b. Observably, Salah al-din and Dahuk provinces recorded the highest $\mathrm{PM}_{2.5}$ concentrations during the study periods. A supplementary file detailing the averages of the daily $\mathrm{PM}_{2.5}$ concentrations for all the studied Iraqi provinces is presented in Fig. 7.

\section{Concentration of $\mathrm{PM}_{10}$}

The observed daily average concentration of $\mathrm{PM}_{10}$ in the Iraqi provinces from March 1 to August 31, 2020, was presented in Fig. 8a. The period from March 1 to March 16, 2020 (1st partial lockdown period) recorded an average daily $\mathrm{PM}_{10}$ concentration of $132 \mu \mathrm{g} / \mathrm{m}^{3}$ which later declined during 1 st total lockdown period (March 17 to April 21, 2020), reaching $112 \mu \mathrm{g} / \mathrm{m}^{3}$ throughout the studied Iraqi provinces. The period of April 22 to May 23, 2020 (the 2nd partial lockdown) recorded the maximum daily $\mathrm{PM}_{10}$ concentration (432 $\mu \mathrm{g} / \mathrm{m}^{3}$ ) with an average value of $173 \mu \mathrm{g} / \mathrm{m}^{3}$ for this period. From May 25 to June 13, 2020, there was an increase in the average daily concentration of $\mathrm{PM}_{10}$ (increased to $177 \mu \mathrm{g} / \mathrm{m}^{3}$ ) due to the implementation of the 2nd total lockdown. From June 142020 to August 20, 2020 , there were fluctuations in the daily average concentration of $\mathrm{PM}_{10}$ as the 3rd partial lockdown was in place, with the average value decreasing to $166 \mu \mathrm{g} / \mathrm{m}^{3}$. However, the end of August witnessed clear declines in the daily average concentration of $\mathrm{PM}_{10}$ (decreased to $125 \mu \mathrm{g} / \mathrm{m}^{3}$ ) as a result of the increased movement of wind and dust particles during the summer period. All the observed daily concentrations of $\mathrm{PM}_{10}$ as recorded in Fig. $8 \mathrm{a}$ exceeded the recommended limit of $50 \mu \mathrm{g} / \mathrm{m}^{3}$ by the WHO. The spatial distribution of the average daily concentrations of $\mathrm{PM}_{10}$ for the studied Iraqi provinces from March 1 to August 31, 2020, is shown in Fig. 8b; observably, the highest level of $\mathrm{PM}_{10}$ was recorded in Salah al-din province during the study period. A supplementary file that detailed the average daily $\mathrm{PM}_{10}$ concentrations for all the Iraqi provinces is provided in Fig. 9.

\section{AQI for 18 provinces in Iraq}

To study the air quality in all the 18 provinces in Iraq during the different phases of lockdown, the levels of different air pollutants were recorded and presented as the AQI for the regions during the studied periods (see Fig. 10a). The period from March 1 to March 16, 2020 (1st partial lockdown period) saw the average AQI values ranging from 88 to 175 and averaged at 120 ; 
Fig. 4 a The average of daily $\mathrm{O}_{3}$ concentrations $\left(\mu \mathrm{g} / \mathrm{m}^{3}\right)$ in provinces of Iraq, during and post the lockdown from the 1 st of March to August 31, 2020. b The spatial distribution of the averages of daily $\mathrm{O}_{3}$ concentrations for 18 Iraqi provinces from the $1 \mathrm{st}$ of

March to August 31, 2020

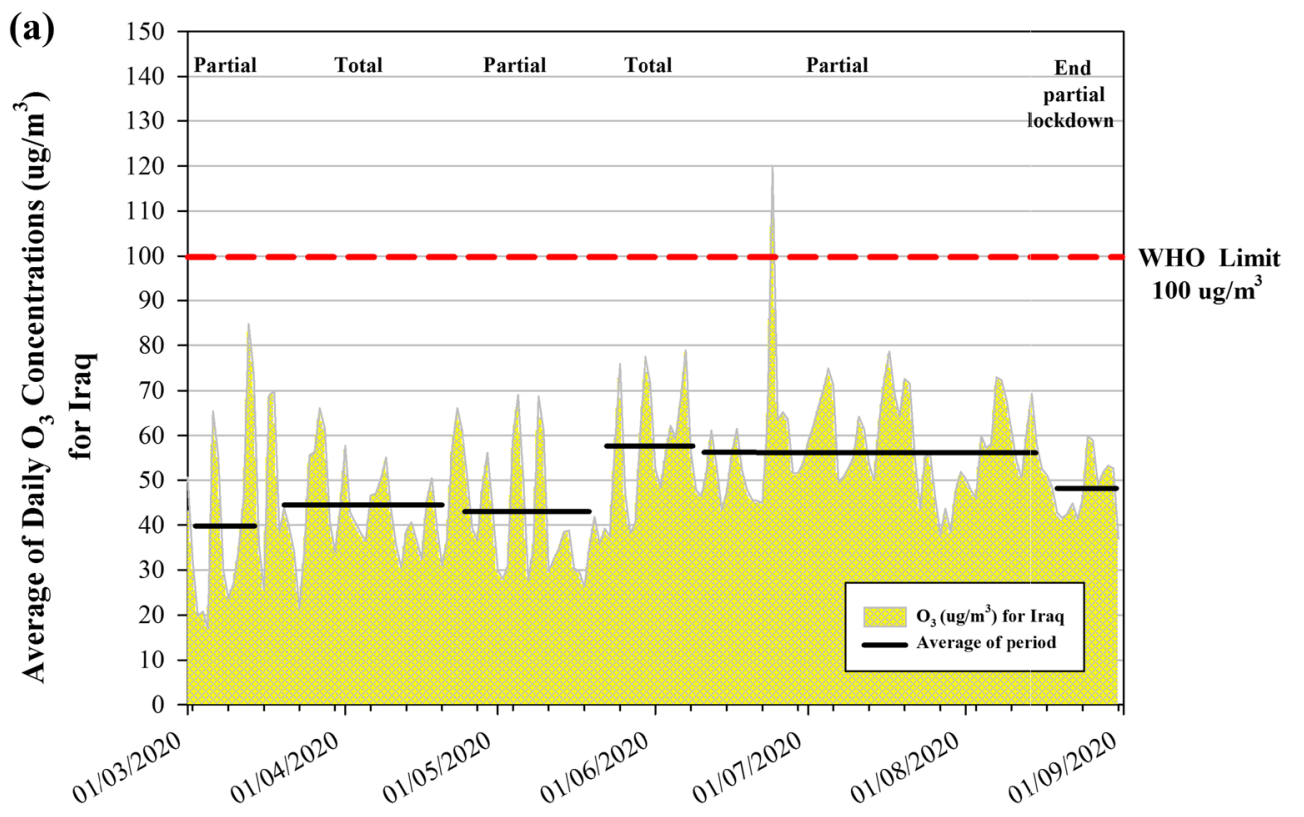

Time

(b)

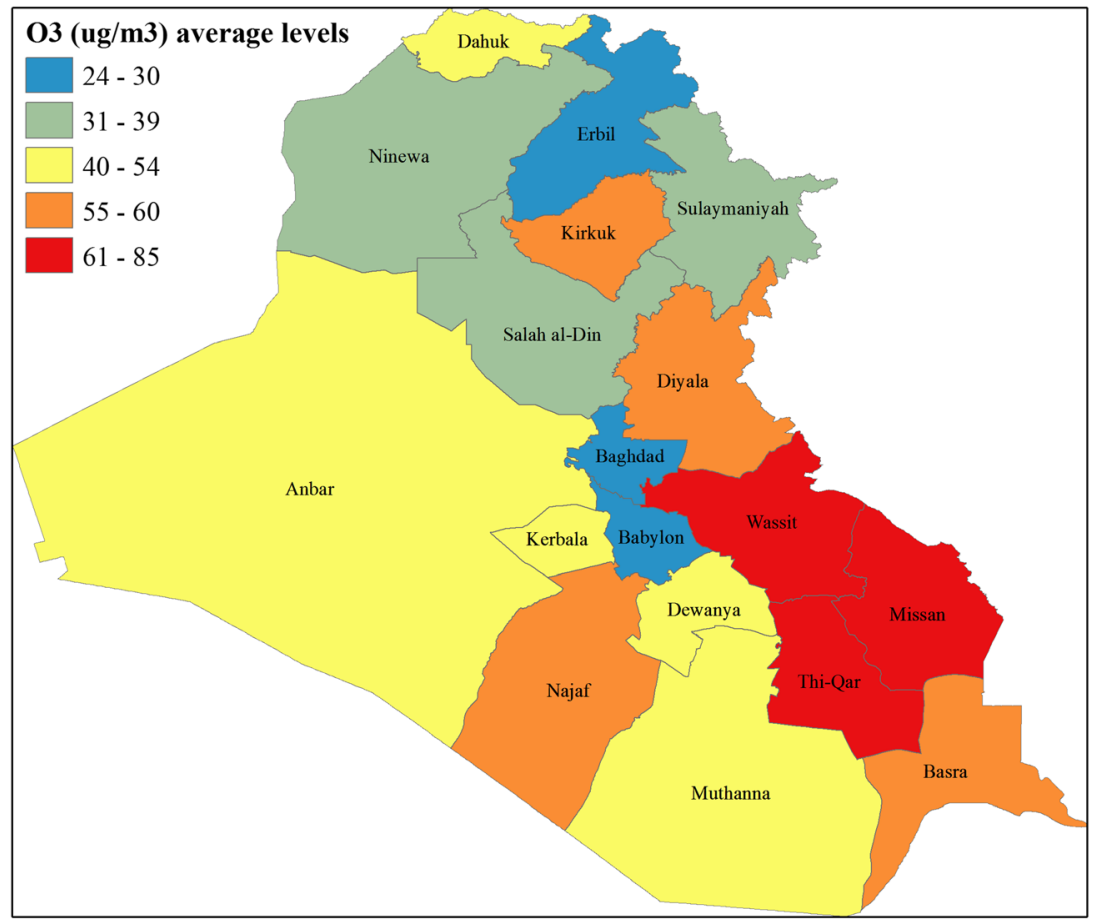


Fig. 5 The average of daily $\mathrm{O}_{3}$ concentrations for provinces of Iraq from March 1 to August 31, 2020

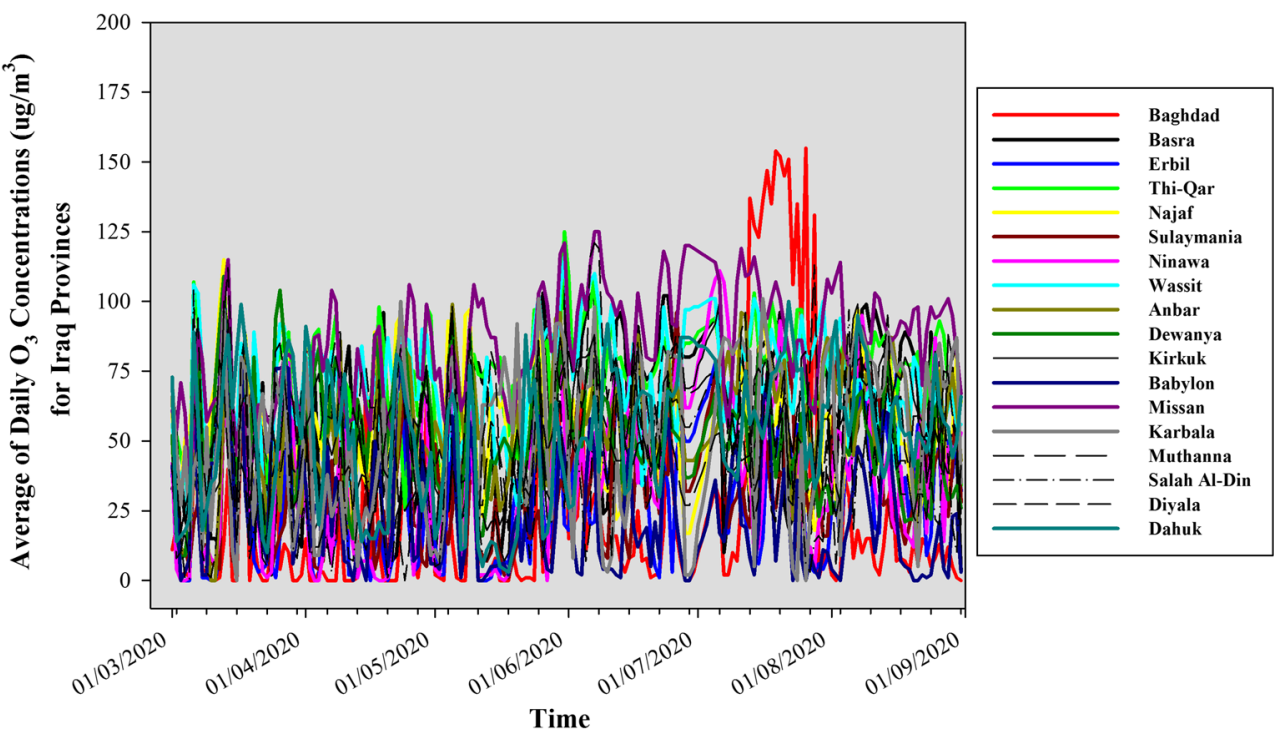

this implies that the AQI level was within the unhealthy level for sensitive persons (3rd level). The 1st total lockdown period (March 17 to April 21, 2020) witnessed improvements in the AQI values in Iraq, with the average value reaching $111(8 \%$ decline in AQI value between the 1 st partial lockdown and 1st total lockdown periods). Iraq witnessed a decline in AQI from April 22 to May 23, 2020 (2nd partial lockdown period); the maximum daily value during this period was 320 , with an average value of 153 . Average values of 157 and 151 were recorded during the 2nd total lockdown and 3rd partial lockdown, respectively (from May 24 to August 20, 2020). The month of August witnessed improvement in the AQI for Iraq as the average value was recorded as 122 . Observably, the period of March-April 2020 (1st total lockdown period) recorded the lowest AQI for Iraq due to the commitment of the citizens to the implemented lockdown measures by the government. These lockdown measures helped to reduce the level of emission of air pollutants into the Iraqi cities as human activities were significantly curtailed. Figure 10b shows the spatial distribution of the average AQI levels for Iraqi provinces from March 1 to August 31, 2020. Among the studied provinces, Basra and Sulaymania provinces recorded the best AQI during the study period. Figure 11 is a supplementary file detailing the average levels of AQI for all the studied Iraqi provinces.

\section{Level of changes in the pollutant concentrations and AQI}

Being that there were no records of the $\mathrm{NO}_{2}, \mathrm{O}_{3}$, $\mathrm{PM}_{2.5}$, and $\mathrm{PM}_{10}$ concentrations for the preceding years, the obtained values in this study were matched against the values from the lockdown and postlockdown periods. The daily $\mathrm{PM}_{2.5}, \mathrm{PM}_{10}$, and $\mathrm{NO}_{2}$ concentrations were significantly reduced by $24 \%$, $15 \%$, and $8 \%$, respectively during the 1 st total lockdown period compared to the 1 st partial lockdown period (see Table 2). Similarly, the average $\mathrm{NO}_{2}$ concentration was significantly reduced during the 2 nd total lockdown period and 3rd partial lockdown period by $10 \%$ and $5 \%$, respectively in comparison to the $1 \mathrm{st}$ period of partial lockdown. The average concentration of $\mathrm{PM}_{2.5}$ continued to reduce by $8 \%, 11 \%$, and $21 \%$ during the 2nd total lockdown period, 3rd partial lockdown period, and post-partial lockdown period respectively, when compared to the 1 st period of partial lockdown. The concentration of $\mathrm{PM}_{10}$ increased by $31 \%, 34 \%$, and $26 \%$, respectively, during the 2 nd partial lockdown period, 2nd total lockdown period, and 3 rd partial lockdown period. From August 20 to 31 (end of lockdown periods), the $\mathrm{PM}_{10}$ concentration was reduced by $5 \%$ in comparison to the 1 st partial lockdown period. Dust particles are the major natural source of suspended air particles in Iraq, due to the prevalence of desert regions in the country. The level of suspended dust particles normally reaches the maximum during the summer and spring periods, due to the influence of the arriving depressions from central Asia and the northern Arabian Gulf (1st National Communication, 2016). On the other hand, transportation activities and emissions from power plants, coupled with the availability of different sizes of generating sets, contribute to the suspended air particles in Iraq (Hashim et al. 2020a). The concentration of $\mathrm{O}_{3}$ showed some levels of fluctuation during the 1 st 
Fig. 6 a The average of daily $\mathrm{PM}_{2.5}$ concentrations $\left(\mu \mathrm{g} / \mathrm{m}^{3}\right)$ in provinces of Iraq, during and post the lockdown from the 1 st of March to August 31, 2020. b The spatial distribution of the averages of daily $\mathrm{PM}_{2.5}$ concentrations for 18 Iraqi provinces from the 1 st of March to August 31, 2020 (a)

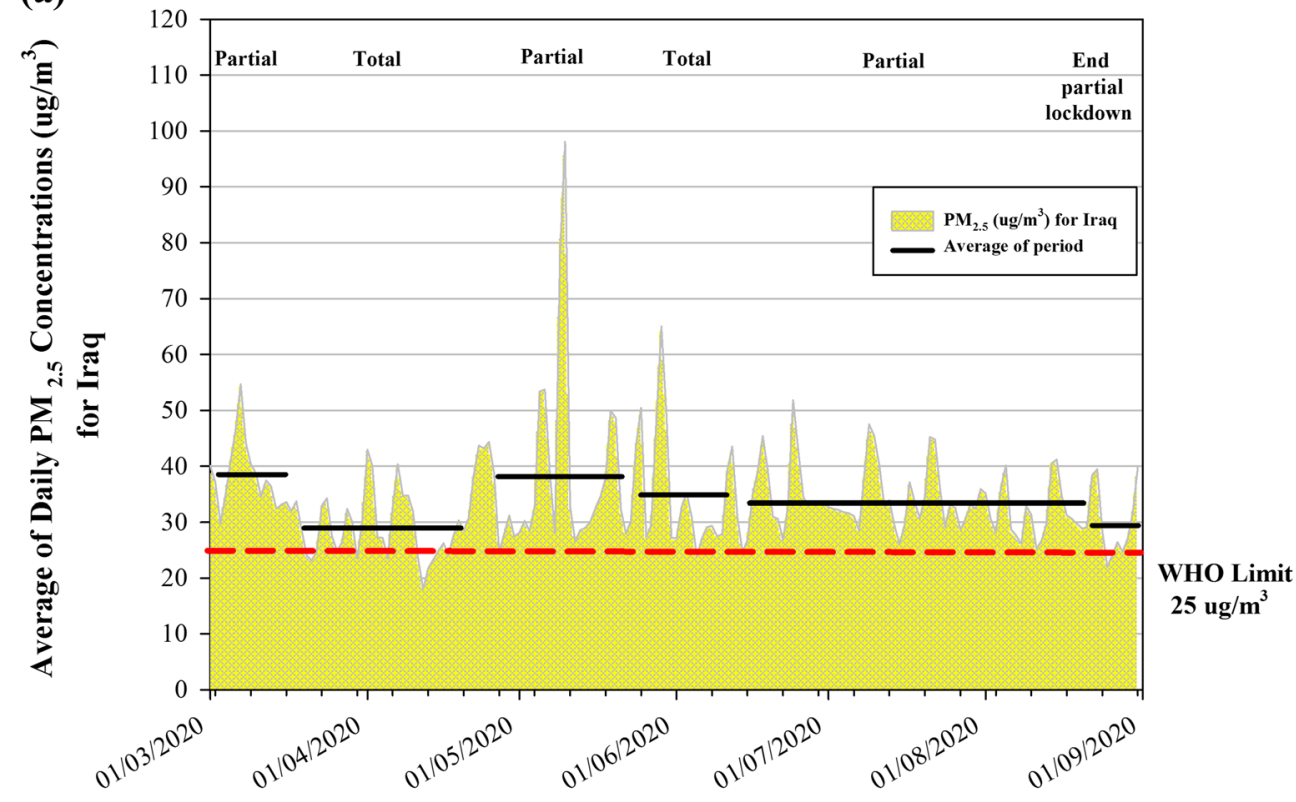

\section{Time}

(b)

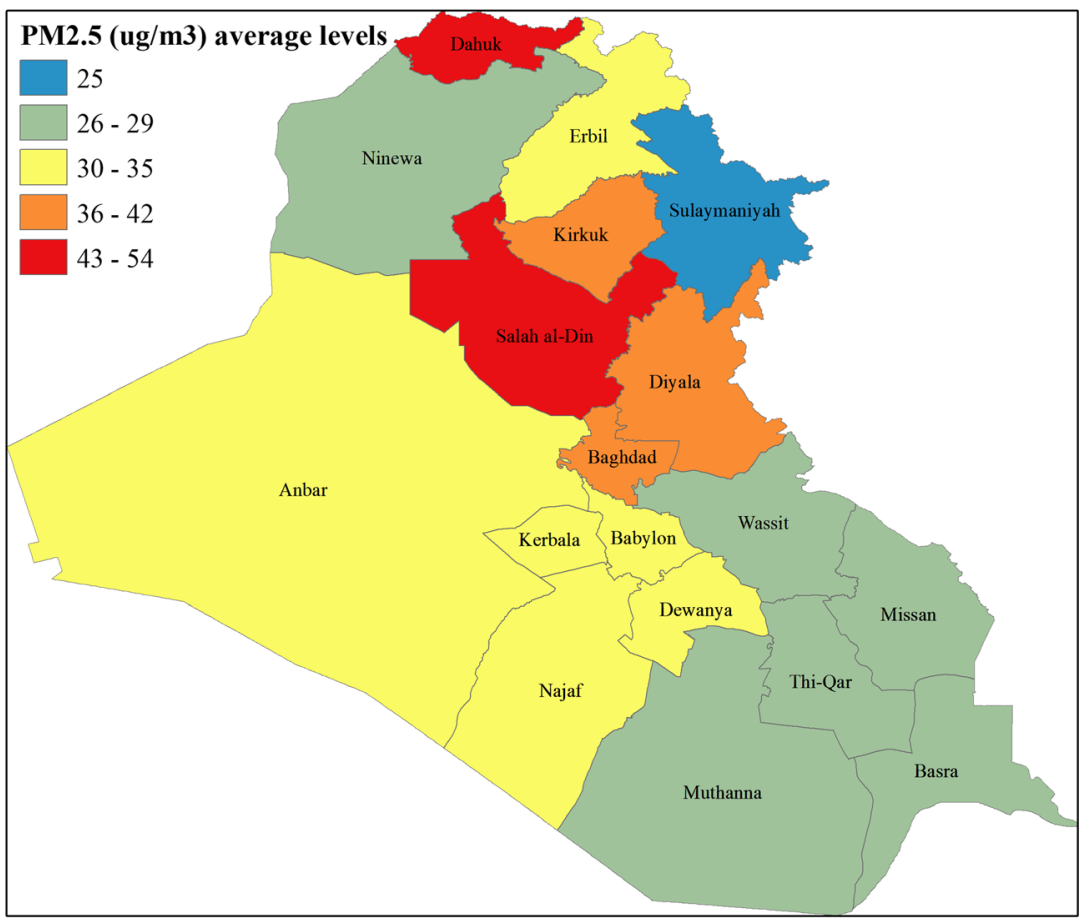


Fig. 7 The average of daily $\mathrm{PM}_{2.5}$ concentrations for provinces of Iraq from March 1 to August 31, 2020

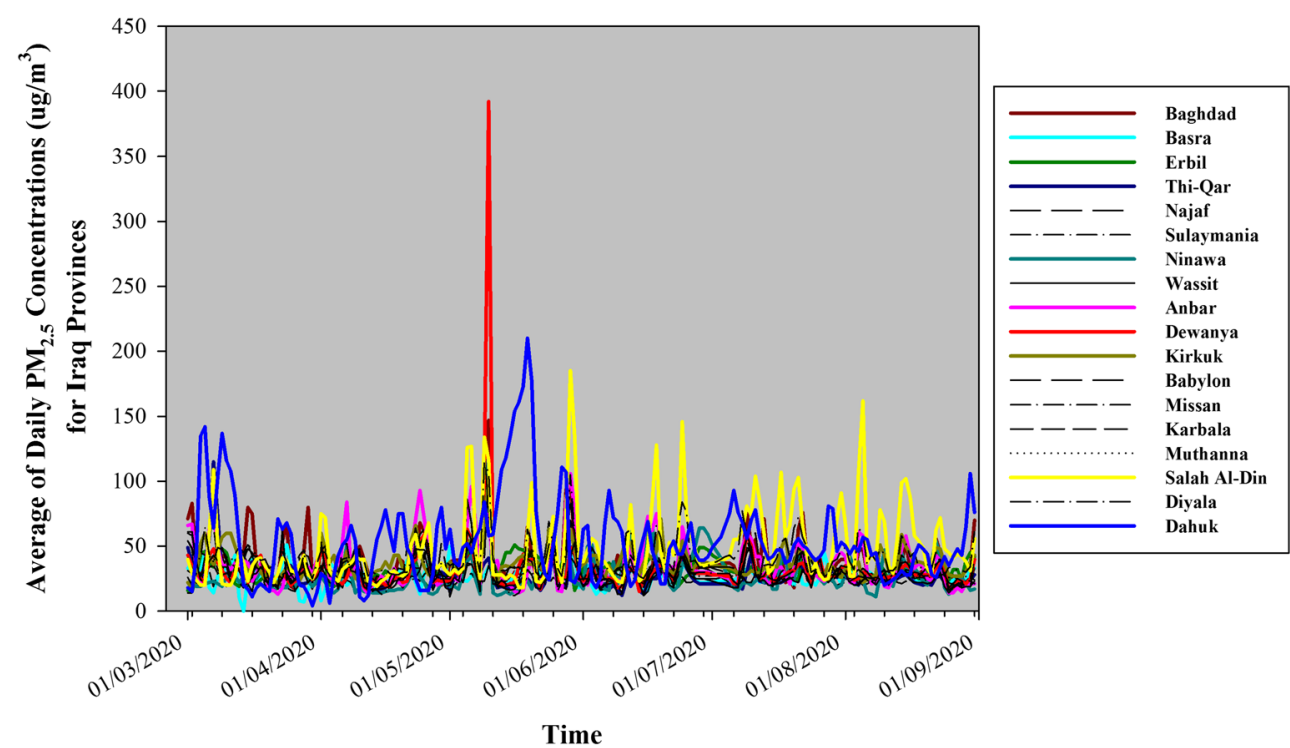

partial lockdown, total, and post-lockdown periods possibly due to increased solar activities during the lockdown periods in Iraq, especially in June and July. On average, the AQI levels in the Iraqi provinces improved by $8 \%$ during the 1 st total lockdown period compared to the pre-lockdown period. But this gain was lost during the months of summer in Iraq, reaching $28 \%, 31 \%$, and $26 \%$ in May, June, and July, respectively. The end of August saw a $2 \%$ improvement in the AQI of the studied Iraqi provinces. Commercial and industrial activities in the large cities of Baghdad, Basra, Mosul, and Erbil contributed to the poor air quality in the whole of Iraq; a high population and vehicular traffic also contributed to the pollution level in Iraq. The dryness and hotness of the country during the summer season also increase the level of suspended particles in the air, thereby deteriorating the quality of air (Ministry of Environment 2016).

The correlation coefficients between the levels of different air pollutants in the studied Iraqi provinces during the lockdown periods and after the suspension of the lockdown measures are presented in Fig. 12 as supplementary material. Observable, there is a significant correlation between the air pollutants; for instance, the $\mathrm{PM}_{2.5}$ and $\mathrm{PM}_{10}$ concentrations showed a high correlation $\left(R^{2}=0.7247\right)$, implying that both are of a common source. Contrarily, a negative correlation existed between $\mathrm{NO}_{2}$ and $\mathrm{O}_{3}, \mathrm{PM}_{2.5}$ and $\mathrm{PM}_{10}$. A significant decrease was observed in the surface $\mathrm{O}_{3}$ concentration as the $\mathrm{NO}_{2}$ increases. At a higher atmospheric $\mathrm{NO}_{2}$ concentration, most of the $\mathrm{NO}_{2}$ reacts with $\mathrm{O}_{3}$ to form $\mathrm{NO}_{2}$ (Monks et al. 2015).

\section{Summary of outcomes}

The modeling results of the current study showed that the daily concentration of $\mathrm{NO}_{2}$ in the 18 provinces of Iraq has decreased during periods of total lockdown, relative to periods of partial lockdown. Baghdad and Babylon recorded the highest concentration of daily levels among the Iraqi provinces. However, these concentrations are within the limit recommended by the WHO which is $200 \mu \mathrm{g} / \mathrm{m}^{3}$. On the contrary, daily $\mathrm{O}_{3}$ concentrations rose to record the highest values in Missan, Wassit, and Thi-Qar. While the lowest values in Baghdad, Babylon, and Erbil. The daily concentrations of $\mathrm{PM}_{2.5}$ exceeded the WHO limit $\left(25 \mu \mathrm{g} / \mathrm{m}^{3}\right)$ during the study period. Salah al-Din and Dahuk topped the provinces of Iraq with the highest daily $\mathrm{PM}_{2.5}$ concentration, while the $\mathrm{PM}_{10}$ concentrations were significantly exceeded the WHO limit $\left(50 \mu \mathrm{g} / \mathrm{m}^{3}\right)$ during periods of partial and total lockdown. Salah al-Din also recorded the highest concentration rate among other provinces. The AQI improved during the 1st total lockdown from March 17 to April 21, in the 18 provinces of Iraq. However, this improvement retreated during the subsequent partial and total lockdown periods, due to the great laxity in applying the measures of the lockdown and social distancing in Iraq. 
Fig. 8 a The average of daily $\mathrm{PM}_{10}$ concentrations $\left(\mu \mathrm{g} / \mathrm{m}^{3}\right)$ in provinces of Iraq, during and post the lockdown from the 1 st of March to August 31, 2020. b The spatial distribution of the averages of daily $\mathrm{PM}_{10}$ concentrations for 18 Iraqi provinces from the 1 st of March to August 31, 2020

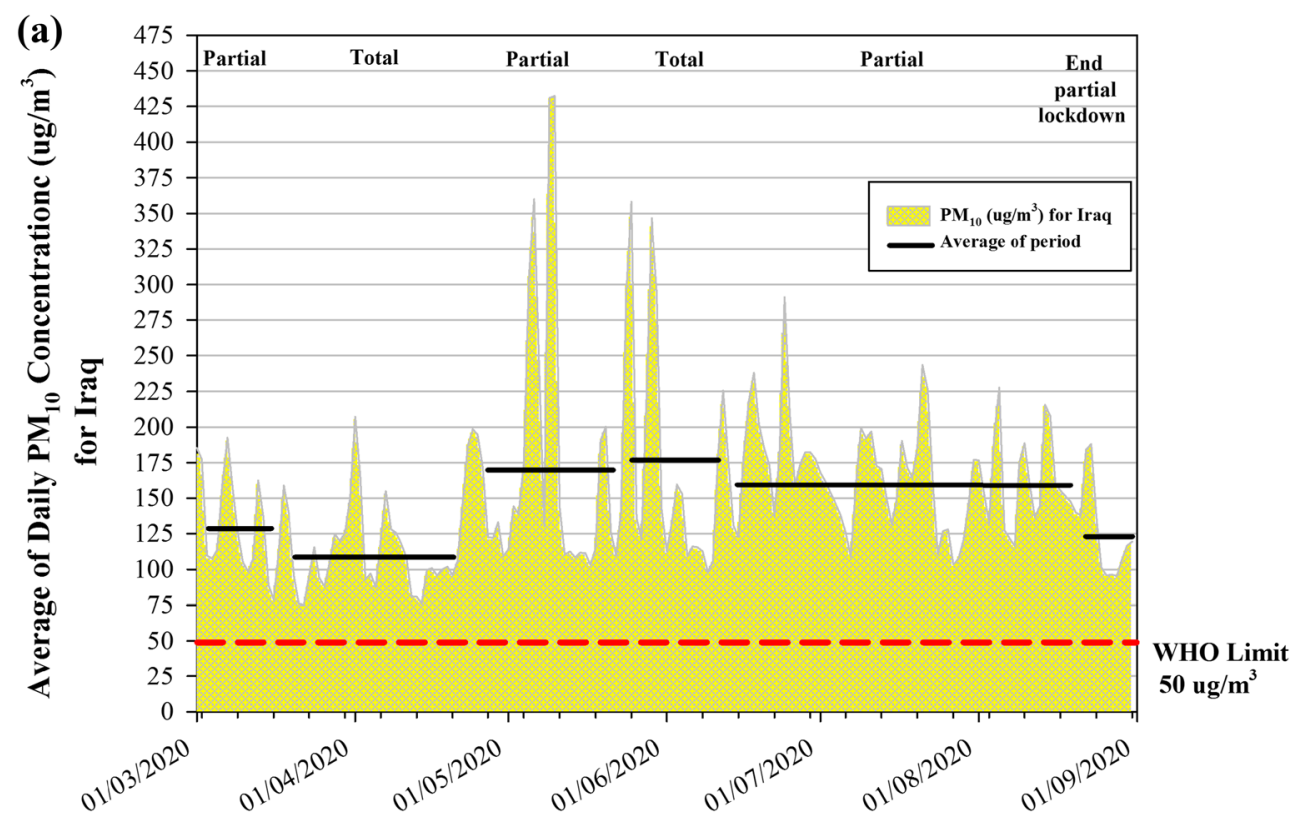

Time

(b)

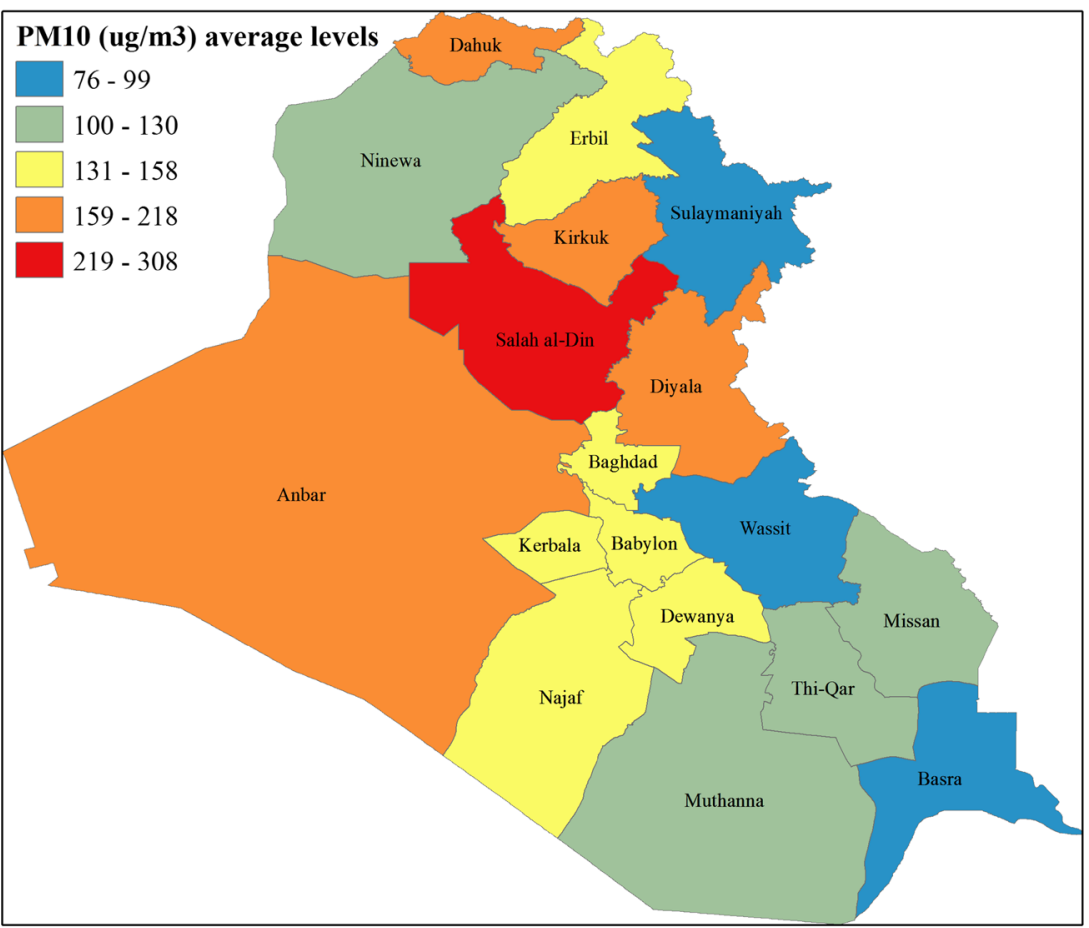


Fig. 9 The average of daily $\mathrm{PM}_{10}$ concentrations for provinces of Iraq from March 1 to August 31, 2020

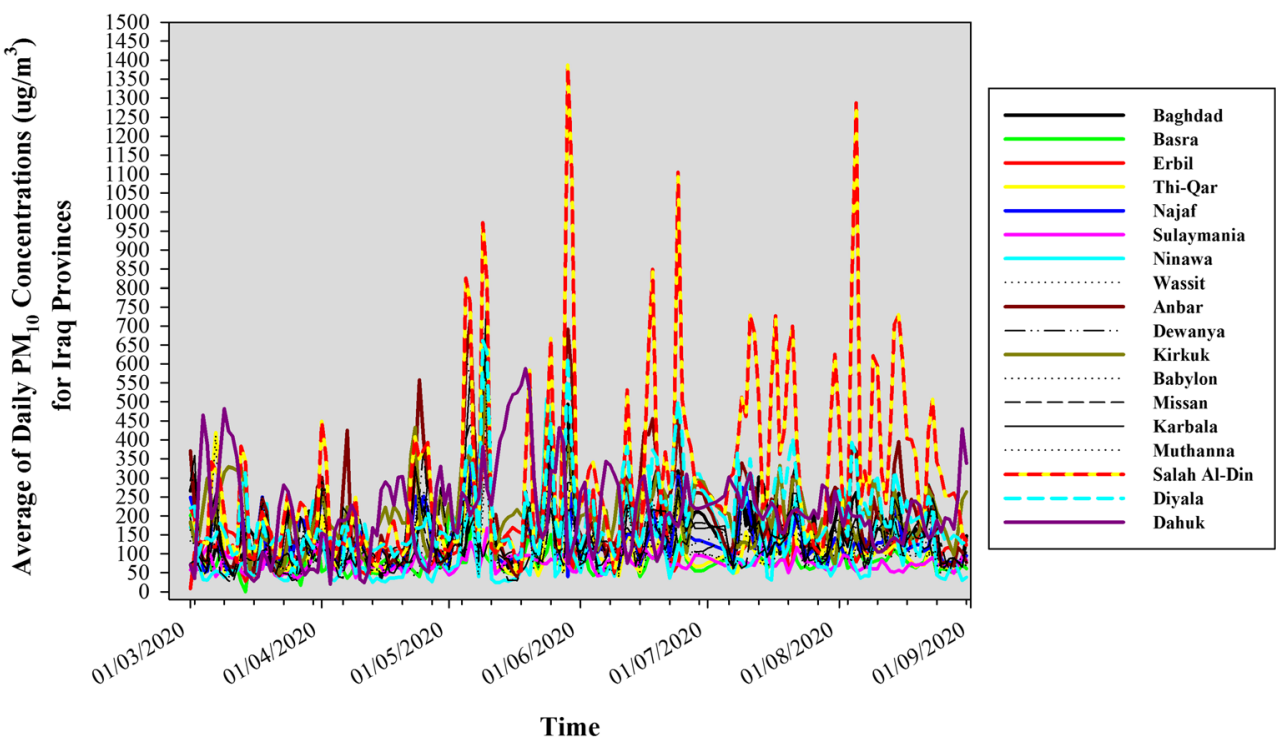

among the largest industrial, residential, and commercial areas.

\section{Conclusion}

The impact of the reduction in human activities on air quality in Iraq during the COVID-19 lockdown and post-lockdown periods was investigated in this study. A substantial decrease $(8 \%, 10 \%$, and $5 \%$ ) was observed in the concentration of $\mathrm{NO}_{2}$ during the 3 phases of complete and partial lockdowns in comparison to the period of 1st partial lockdown. Furthermore, the average $\mathrm{PM}_{2.5}$ and $\mathrm{PM}_{10}$ concentrations reduced by $24 \%$ and $15 \%$, respectively in the studied provinces of Iraq during the period of 1st total lockdown. It was observed that Iraq consistently records higher levels of $\mathrm{PM}_{2.5}$ and $\mathrm{PM}_{10}$ even before the lockdown period as the observed daily periods pre-COVID-19 normally exceed the recommended limit by the WHO. This is evidence of the contribution of natural elements to the poor air quality in Iraq. The $\mathrm{O}_{3}$ concentration was improved by $10 \%$, $8 \%, 45 \%, 43 \%$, and $23 \%$ during the 1 st partial lockdown, the partial lockdown, total lockdown, and postlockdown periods as a result of the reduction in the concentrations of $\mathrm{NO}_{2}$ and $\mathrm{PM}_{10}$. The 1st total lockdown period in Iraq witnessed an average of an $8 \%$ increase in AQI in comparison to the 1st partial lockdown period. However, this improvement was lost during May, June, and July due to the increased suspension 
Fig. 10 a AQI for Iraq from the 1st of March to August 31, 2020. b The spatial distribution of the AQI average levels for 18 Iraqi provinces from the 1st of March to August 31, 2020 (a)

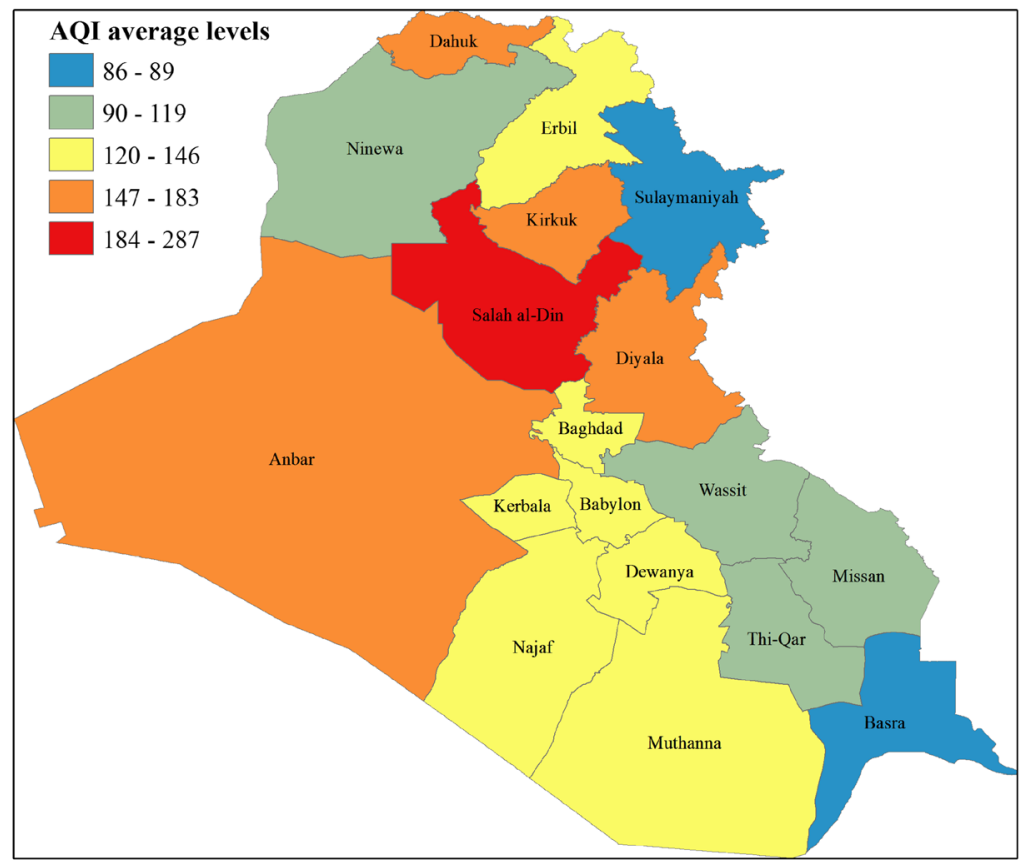

(b)

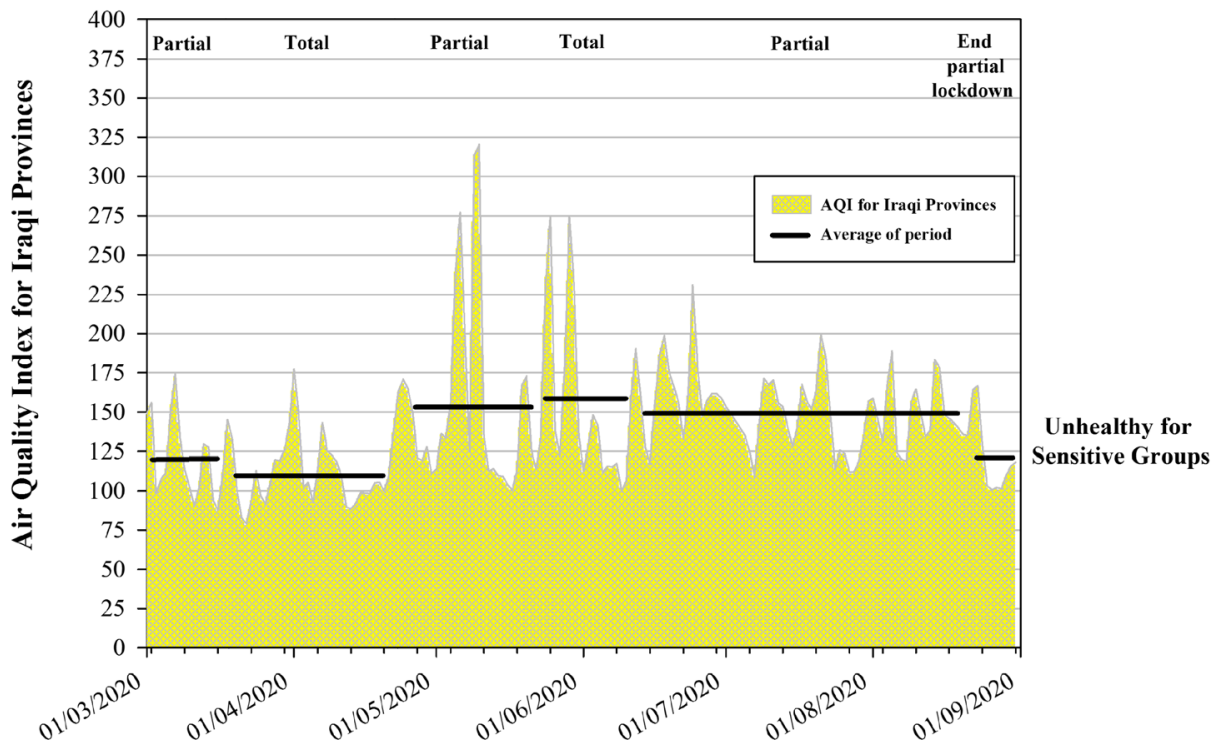

Time 
Fig. 11 The average of AQI levels for all provinces of Iraq from March 1 to August 31, 2020

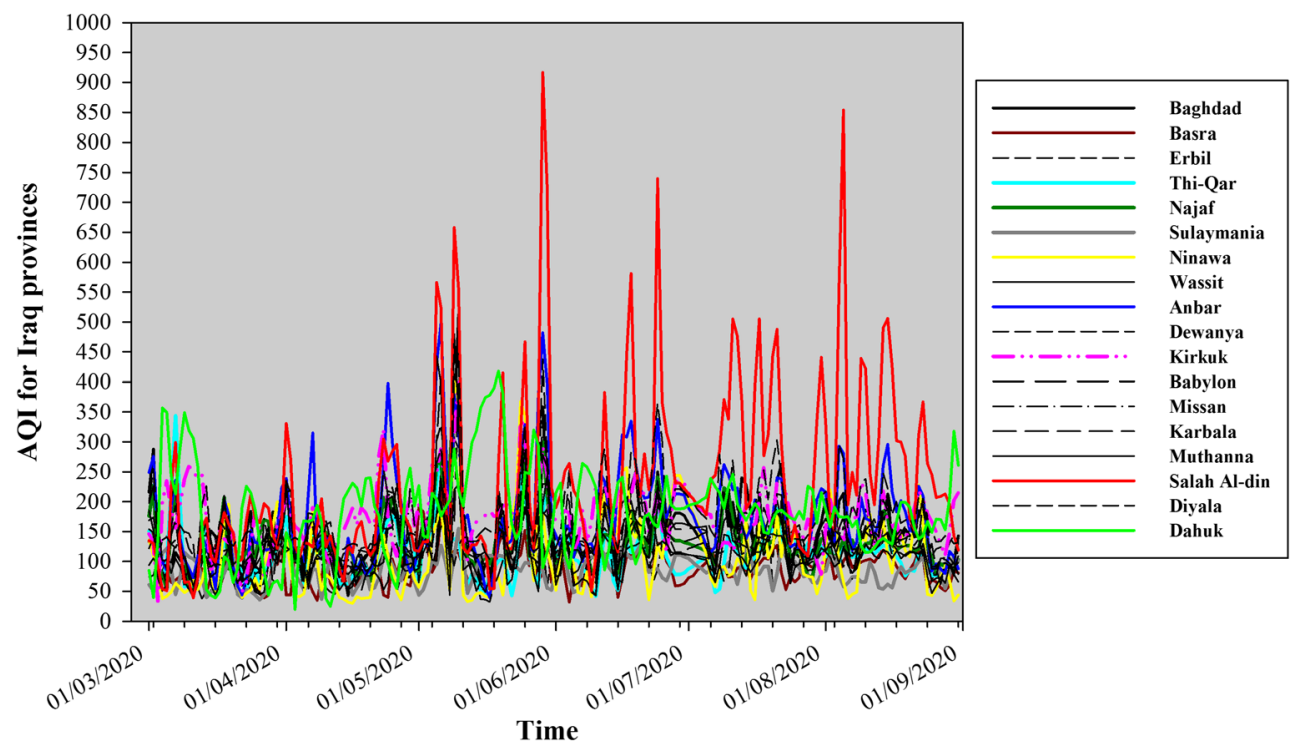

of dust particles during the summer months. The lockdown measures aimed at containing the spread of COVID-19 but the impact was greatly felt in the industrial and transport sectors, causing reductions in oil demand and energy consumption. Despite the economic hardships associated with the COVID-19 lockdown measures, one significant benefit of the implemented measures is the improvement in air quality throughout the globe.

This research limited with focus to known the percent variation in air pollution concentration and air quality index during the COVID-19 partial, total, and post-lockdown in 18 provinces of Iraq. But future studies will consider the relationship between the air pollutants and meteorological variables as well as the effect of the COVID-19 on surface water quality during prelockdown, lockdown, and post-lockdown periods over the study area with the help of statistical and geospatial techniques. Likewise, future research will investigate the prediction of air pollutants, AQI, and water quality index by employing the stochastic and machine learning models in the study region.
Table 2 Percentage changes of average $\mathrm{NO}_{2}, \mathrm{O}_{3}, \mathrm{PM}_{2.5}, \mathrm{PM}_{10}$ concentrations, and AQI in Iraqi provinces, between March 1 to August 31, 2020, during the partial, total, and post-lockdown periods

\begin{tabular}{|c|c|c|c|c|c|}
\hline Period & $\begin{array}{l}\text { Average of } \\
\mathrm{NO}_{2}\end{array}$ & $\begin{array}{l}\text { Average } \\
\text { of } \mathrm{O}_{3}\end{array}$ & $\begin{array}{l}\text { Average of } \\
\mathrm{PM}_{2.5}\end{array}$ & $\begin{array}{l}\text { Average of } \\
\mathrm{PM}_{10}\end{array}$ & $\begin{array}{l}\text { Average of } \\
\text { AQI }\end{array}$ \\
\hline $\begin{array}{l}\text { March } 1 \text { to } 16 \text { (during the } 1 \text { st partial } \\
\text { lockdown) }\end{array}$ & 42 & 40 & 38 & 132 & 120 \\
\hline $\begin{array}{l}\text { March } 17 \text { to April } 21 \text { (during 1st } \\
\text { total lockdown) }\end{array}$ & 39 & 44 & 29 & 112 & 111 \\
\hline Percent reduction & $-8 \%$ & $10 \%$ & $-24 \%$ & $-15 \%$ & $-8 \%$ \\
\hline $\begin{array}{l}\text { April 22-May } 23 \text { (during the } 2 \text { nd } \\
\text { partial lockdown) }\end{array}$ & 42 & 43 & 38 & 173 & 153 \\
\hline Percent reduction & $0 \%$ & $8 \%$ & $0 \%$ & $31 \%$ & $28 \%$ \\
\hline $\begin{array}{l}\text { May } 24 \text { to June } 13 \text { (during } 2 \text { nd total } \\
\text { lockdown) }\end{array}$ & 38 & 58 & 35 & 177 & 157 \\
\hline Percent reduction & $-10 \%$ & $45 \%$ & $-8 \%$ & $34 \%$ & $31 \%$ \\
\hline $\begin{array}{l}\text { June14 to August } 20 \text { (during } 3 \text { rd } \\
\text { partial lockdown) }\end{array}$ & 40 & 57 & 34 & 166 & 151 \\
\hline Percent reduction & $-5 \%$ & $43 \%$ & $-11 \%$ & $26 \%$ & $26 \%$ \\
\hline $\begin{array}{l}\text { August } 21 \text { to } 31 \text { (end partial } \\
\text { lockdown) }\end{array}$ & 46 & 49 & 30 & 125 & 122 \\
\hline Percent reduction & $10 \%$ & $23 \%$ & $-21 \%$ & $-5 \%$ & $2 \%$ \\
\hline
\end{tabular}



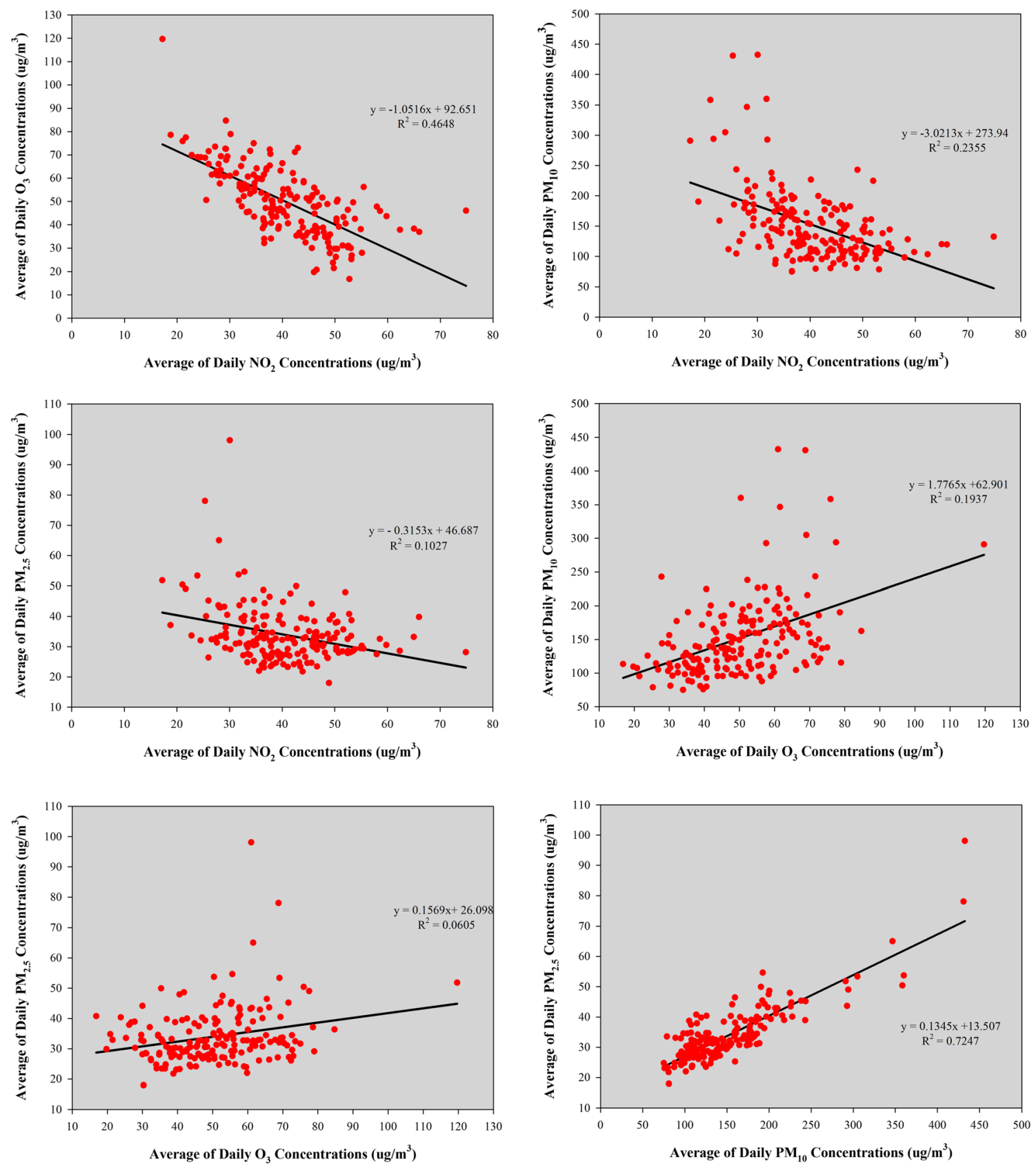

Fig. 12 The correlation coefficients between air pollutants $\left(\mathrm{NO}_{2}, \mathrm{O}_{3}, \mathrm{PM}_{2.5}\right.$, and $\left.\mathrm{PM}_{10}\right)$ in air of Iraqi provinces, during and post the lockdown from March 1 to August 31, 2020 
Acknowledgements The authors acknowledge the support received by the Ministry of Higher Education and Scientific Research, Baghdad, Iraq.

Author contribution Bassim Mohammed Hashim: Conceptualization, formal analysis, modeling, writing the manuscript content, visualization. Saadi K. Al-Naseri: Conceptualization, formal analysis, modeling, writing the manuscript content, visualization. Ali Al- Maliki: Conceptualization, formal analysis, modeling, writing the manuscript content, visualization. Zulfaqar Sa'adi: Conceptualization, formal analysis, modeling, writing the manuscript content, visualization. Anurag Malik: Conceptualization, formal analysis, modeling, writing the manuscript content, visualization. Zaher Mundher Yaseen: Conceptualization, supervision, formal analysis, modeling, writing the manuscript content, visualization.

Availability of data and materials Data were obtained from an opensource website and presented in the manuscript itself.

\section{Declarations}

Ethical approval The manuscript is conducted within the ethical manner advised by the Environmental Science and Pollution Research.

\section{Consent to participate Not applicable.}

Consent to publish The research is scientifically consented to be published.

Conflict of interest The authors declare no competing interests.

\section{References}

Al-Ansari N, AlJawad S, Adamo N et al (2018) Water quality within the Tigris and Euphrates catchments: water quality within the Tigris and Euphrates catchments. J Earth Sci Geotech Eng 8:95-121

Bao R, Zhang A (2020) Does lockdown reduce air pollution? Evidence from 44 cities in northern China. Sci Total Environ 731:139052. https://doi.org/10.1016/j.scitotenv.2020.139052

Bashir MF, Ma B, Shahzad L (2020) A brief review of socio-economic and environmental impact of Covid-19. Air Qual Atmos Health 13: 1-7. https://doi.org/10.1007/s11869-020-00894-8

Begum BA, Hopke PK, Markwitz A (2013) Air pollution by fine particulate matter in Bangladesh. Atmos Pollut Res 4:75-86. https://doi. org/10.5094/apr.2013.008

Bhat SA, Bashir O, Bilal M, Ishaq A, Din Dar MU, Kumar R, Bhat RA, Sher F (2021) Impact of COVID-related lockdowns on environmental and climate change scenarios. Environ Res 195:110839. https:// doi.org/10.1016/j.envres.2021.110839

Bherwani H, NairM, Musugu K, Gautam S, Gupta A, Kapley A, Kumar R (2020) Valuation of air pollution externalities: comparative assessment of economic damage and emission reduction under COVID-19 lockdown. Air Qual Atmos Health 13:1-12. https:// doi.org/10.1007/s11869-020-00845-3

Burke M (2020) COVID-19 reduces economic activity, which reduces pollution, which saves lives (March 8, 2020). http://www.g-feed. com/2020/03/covid-19-reduces-economic-Act Accessed 06/09/ 2020

Cárcel-Carrasco J, Pascual-Guillamón M, Langa-Sanchis J (2021) Analysis of the effect of COVID-19 on air pollution: perspective of the Spanish case. Environ Sci Pollut Res. https://doi.org/10. 1007/s11356-021-13301-1
Chabuk A, Al-Madhlom Q, Al-Maliki A et al (2020) Water quality assessment along Tigris River (Iraq) using water quality index (WQI) and GIS software. Arab J Geosci 13. https://doi.org/10.1007/ s12517-020-05575-5

Chu B, Zhang S, Liu J et al (2020) Significant concurrent decrease in PM2. 5 and NO2 concentrations in China during COVID-19 epidemic. J Environ Sci 99:346-353

Cohen AJ, Brauer M, Burnett R, Anderson HR, Frostad J, Estep K, Balakrishnan K, Brunekreef B, Dandona L, Dandona R, Feigin V, Freedman G, Hubbell B, Jobling A, Kan H, Knibbs L, Liu Y, Martin R, Morawska L, Pope CA III, Shin H, Straif K, Shaddick G, Thomas M, van Dingenen R, van Donkelaar A, Vos T, Murray CJL, Forouzanfar MH (2017) Estimates and 25-year trends of the global burden of disease attributable to ambient air pollution: an analysis of data from the Global Burden of Diseases Study 2015. Lancet 389: 1907-1918. https://doi.org/10.1016/S0140-6736(17)30505-6

Collivignarelli MC, Abbà A, Bertanza G, Pedrazzani R, Ricciardi P, Carnevale Miino M (2020) Lockdown for CoViD-2019 in Milan: what are the effects on air quality? Sci Total Environ 732:139280. https://doi.org/10.1016/j.scitotenv.2020.139280

Dantas G, Siciliano B, França BB, da Silva CM, Arbilla G (2020) The impact of COVID-19 partial lockdown on the air quality of the city of Rio de Janeiro, Brazil. Sci Total Environ 729:139085. https://doi. org/10.1016/j.scitotenv.2020.139085

Das M, Das A, Sarkar R, et al (2020) Examining the impact of lockdown (due to COVID-19) on ambient aerosols (PM2.5): a study on IndoGangetic Plain (IGP) Cities, India. Stoch Environ Res Risk Assess. https://doi.org/10.1007/s00477-020-01905-x

Frenken K (2009) Irrigation in the Middle East region in figures, AQUASTAT Survey-2008. FAO water reports Publ by food Agric Organ United Nations (FAO), Rome, Italy, 34 ISSN 1020120

Gautam S, Hens L (2020) COVID-19: impact by and on the environment, health and economy. Environ Dev Sustain 22:1-2. https://doi.org/ 10.1007/s10668-020-00818-7

Gautam S, Trivedi U (2020) Global implications of bio-aerosol in pandemic. Environ Dev Sustain 22:3861-3865. https://doi.org/10.1007/ s10668-020-00704-2

Hashim BM, Al-Naseri SK, Al-Maliki A, Al-Ansari N (2020a) Impact of COVID-19 lockdown on NO2, O3, PM2.5 and PM10 concentrations and assessing air quality changes in Baghdad, Iraq. Sci Total Environ 754:141978. https://doi.org/10.1016/j.scitotenv.2020. 141978

Hashim BM, Sultan MA, Al Maliki A, Al-Ansari N (2020b) Estimation of greenhouse gases emitted from energy industry (oil refining and electricity generation) in Iraq using IPCC methodology. Atmosphere (Basel) 11:662. https://doi.org/10.3390/ atmos11060662

Hassan MS, Bhuiyan MAH, Tanu SM, et al (2020) Spatial relationships between COVID-19 infection rates and air pollution, geometeorological and social parameters in Dhaka, Bangladesh. https://doi.org/10.21203/rs.3.rs-39091/v1

He G, Pan Y, Tanaka T (2020) The short-term impacts of COVID-19 lockdown on urban air pollution in China. Nat Sustain 3:10051011. https://doi.org/10.1038/s41893-020-0581-y

Huang C, Wang Y, Li X et al (2020) Clinical features of patients infected with 2019 novel coronavirus in Wuhan, China. Lancet (London, England) 395:497-506. https://doi.org/10.1016/S0140-6736(20) 30183-5

IEA (International Energy Agency) (2012) Iraq energy outlook: world energy outlook special report, p. 142. Available online. http://www. worldenergyoutlook.org (Accessed 20 June 2020)

Jassim HM, Ibraheem FH, Zangana BFA (2014) Environmental issues caused by the increasing number of vehicles in Iraq. Energy Sustain. V. https://doi.org/10.2495/ESUS140291 
Jebril N (2020) Impact of the COVID-19 Pandemic on the environmenta case study of Iraq. SSRN Electron J. https://doi.org/10.2139/ssrn. 3597426

Kerimray A, Baimatova N, Ibragimova OP, Bukenov B, Kenessov B, Plotitsyn P, Karaca F (2020) Assessing air quality changes in large cities during COVID-19 lockdowns: the impacts of traffic-free urban conditions in Almaty, Kazakhstan. Sci Total Environ 730: 139179. https://doi.org/10.1016/j.scitotenv.2020.139179

Khan R, Saxena A, Shukla S, Sekar S, Goel P (2021) Effect of COVID19 lockdown on the water quality index of River Gomti, India, with potential hazard of faecal-oral transmission. Environ Sci Pollut Res. https://doi.org/10.1007/s11356-021-13096-1

Lelieveld J, Evans JS, Fnais M, Giannadaki D, Pozzer A (2015) The contribution of outdoor air pollution sources to premature mortality on a global scale. Nature 525:367-371. https://doi.org/10.1038/ nature 15371

Li Q, Guan X, Wu P, Wang X, Zhou L, Tong Y, Ren R, Leung KSM, Lau EHY, Wong JY, Xing X, Xiang N, Wu Y, Li C, Chen Q, Li D, Liu T, Zhao J, Liu M, Tu W, Chen C, Jin L, Yang R, Wang Q, Zhou S, Wang R, Liu H, Luo Y, Liu Y, Shao G, Li H, Tao Z, Yang Y, Deng Z, Liu B, Ma Z, Zhang Y, Shi G, Lam TTY, Wu JT, Gao GF, Cowling BJ, Yang B, Leung GM, Feng Z (2020) Early transmission dynamics in Wuhan, China, of novel coronavirus-infected pneumonia. N Engl J Med 382:1199-1207. https://doi.org/10.1056/ NEJMoa2001316

Long HW, Feng WJ (2020) Research Report on Companies' Survival and Development Strategy During a Novel Coronavirus Epidemic. UIBE Press: Beijing

Lu R, Zhao X, Li J et al (2020) Genomic characterisation and epidemiology of 2019 novel coronavirus: implications for virus origins and receptor binding. Lancet (London, England) 395:565-574. https:// doi.org/10.1016/S0140-6736(20)30251-8

Ministry of Environment (2016) Environment situation in Iraq: Baghdad, Iraq. 282. http://www.moen.gov.iq/Portals/0/2016

Ministry of Health (2020) Daily situations of COVID-19 in Iraq. www. moh.gov.iq. Accessed 10 Sept 2020

Monks PS, Archibald AT, Colette A, Cooper O, Coyle M, Derwent R, Fowler D, Granier C, Law KS, Mills GE, Stevenson DS, Tarasova O, Thouret V, von Schneidemesser E, Sommariva R, Wild O, Williams ML (2015) Tropospheric ozone and its precursors from the urban to the global scale from air quality to short-lived climate forcer. Atmos Chem Phys 15:8889-8973. https://doi.org/10.5194/ acp-15-8889-2015

Motesaddi S, Hashempour Y, Nowrouz P (2017) Characterizing of air pollution in Tehran: comparison of two air quality indices. Civ Eng J 3:749-758. https://doi.org/10.21859/cej-030911

Munster VJ, Koopmans M, van Doremalen N, van Riel D, de Wit E (2020) A novel coronavirus emerging in China - key questions for impact assessment. N Engl J Med 382:692-694. https://doi. org/10.1056/nejmp2000929

Nakada LYK, Urban RC (2020) COVID-19 pandemic: impacts on the air quality during the partial lockdown in São Paulo state, Brazil. Sci Total Environ 730:139087. https://doi.org/10.1016/j.scitotenv.2020. 139087

Nuvolone D, Petri D, Voller F (2017) The effects of ozone on human health. Environ Sci Pollut Res 25:8074-8088. https://doi.org/10. 1007/s11356-017-9239-3

Pata UK (2020) How is COVID-19 affecting environmental pollution in US cities? Evidence from asymmetric Fourier causality test. Air Qual Atmos Health 13:1-7. https://doi.org/10.1007/s11869-02000877-9

Salman S, Shahid S, Afan H, Shiru M, Al-Ansari N, Yaseen Z (2020) Changes in Climatic Water Availability and Crop Water Demand for Iraq Region. Sustainability MDPI123437:20. https://doi.org/10. 3390/su12083437
Shakil MH, Munim ZH, Tasnia M, Sarowar S (2020) COVID-19 and the environment: a critical review and research agenda. Sci Total Environ 745:141022. https://doi.org/10.1016/j.scitotenv.2020. 141022

Sharifi A, Khavarian-Garmsir AR (2020) The COVID-19 pandemic: impacts on cities and major lessons for urban planning, design, and management. Sci Total Environ 142391

Sharma S, Zhang M, Anshika et al (2020) Effect of restricted emissions during COVID-19 on air quality in India. Sci Total Environ 728: 138878. https://doi.org/10.1016/j.scitotenv.2020.138878

Shehzad K, Sarfraz M, Shah SGM (2020) The impact of COVID-19 as a necessary evil on air pollution in India during the lockdown. Environ Pollut 266:115080. https://doi.org/10.1016/j.envpol.2020. 115080

Shi H, Han X, Jiang N, Cao Y, Alwalid O, Gu J, Fan Y, Zheng C (2020) Radiological findings from 81 patients with COVID-19 pneumonia in Wuhan, China: a descriptive study. Lancet Infect Dis 20:425434. https://doi.org/10.1016/S1473-3099(20)30086-4

Sicard P, Serra R, Rossello P (2016) Spatiotemporal trends in groundlevel ozone concentrations and metrics in France over the time period 1999-2012. Environ Res 149:122-144. https://doi.org/10. 1016/j.envres.2016.05.014

Sicard P, Khaniabadi YO, Perez S, Gualtieri M, de Marco A (2019) Effect of O3, PM10 and PM2.5 on cardiovascular and respiratory diseases in cities of France, Iran and Italy. Environ Sci Pollut Res 26:3264532665. https://doi.org/10.1007/s11356-019-06445-8

Sulaymon ID, Zhang Y, Hopke PK, Zhang Y, Hua J, Mei X (2021) COVID-19 pandemic in Wuhan: ambient air quality and the relationships between criteria air pollutants and meteorological variables before, during, and after lockdown. Atmos Res 250:105362. https:// doi.org/10.1016/j.atmosres.2020.105362

The World Bank (2006) Iraq-country water resource assistance strategy: addressing major threats to people's livelihoods. Water, Environment, Social and Rural Development Department Middle East and North Africa Region. http://documents.worldbank.org/ curated/en/944501468253199270/pdf/362970IQ.pdf. Accessed 20 Dec 2020

Tung NT, Huang JZ, Nguyen TT, Khan I (2014) Bias-corrected quantile regression forests for high-dimensional data. 2014 Int. Conf. Mach. Learn. Cybern.

Tusher TR, Ashraf Z, Akter S (2019) Health effects of brick kiln operations: a study on largest brick kiln cluster in Bangladesh. South East Asia J Public Heal 8:32-36. https://doi.org/10.3329/seajph.v8i1. 42270

U.S. Environmental Protection Agency (EPA) (2020a) Nitrogen dioxide (NO2) pollution. https://www.epa.gov/no2-pollution/basicinformation-about-no2\#What is NO2, Accessed 06/10/2020

U.S. Environmental Protection Agency (EPA) (2020b) Particulate matter (PM) pollution. https://www.epa.gov/pm-pollution/particulatematter-pm-basics\#PM, Accessed 06/10/2020

United Nations (2019) World urbanization prospects 2018 - highlights. Dep Econ Soc Aff Popul Div (ST/ESA/SERA/421)

Vulichi SR, Kabra A, Khalid M, Kumar R, Cruz-Martins N (2021) Interlink between pollution and COVID-19 in India: compelling view and key attributes. Environ Sci Pollut Res. https://doi.org/10. 1007/s11356-021-13451-2

Wang Q, Su M (2020) Drivers of decoupling economic growth from carbon emission - an empirical analysis of 192 countries using decoupling model and decomposition method. Environ Impact Assess Rev 81:106356. https://doi.org/10.1016/j.eiar.2019.106356

WHO (World Health Organization) (2006) WHO Air Quality Guidelines for Particulate Matter, Ozone, Nitrogen Dioxide and Sulfur Dioxide - Global Update 2005 - Summary of Risk Assessment. World Health Organization: Denmark (WHO/SDE/PHE/OEH/06.02) 
WHO (World Health Organization) (2019) Global health observatory data. https://www.who.int/gho/phe/outdoor_air_pollution/burden/ en/.t. Accessed 13 Oct 2020.

WHO (World Health Organization) (2020) Novel coronavirus (2019nCoV). http://www.euro.who.int/en/health-topics/healthemergencies/novel-coronavirus-2019-ncov_old. Accessed 05 Oct 2020

World Air Map (2020) Available online: https://air.plumelabs.com/en/ (Accessed on 9.1.20).

Wu Z, McGoogan JM (2020) Characteristics of and important lessons from the coronavirus disease 2019 (COVID-19) outbreak in China. JAMA 323:1239-1242. https://doi.org/10.1001/jama.2020.2648

Xu B, Gutierrez B, Mekaru S, Sewalk K, Goodwin L, Loskill A, Cohn EL, Hswen Y, Hill SC, Cobo MM, Zarebski AE, Li S, Wu CH,
Hulland E, Morgan JD, Wang L, O’Brien K, Scarpino SV, Brownstein JS, Pybus OG, Pigott DM, Kraemer MUG (2020a) Epidemiological data from the COVID-19 outbreak, real-time case information. Sci data 7:106. https://doi.org/10.1038/s41597-0200448-0

Xu K, Cui K, Young L-H et al (2020b) Air quality index, indicatory air pollutants and impact of COVID-19 event on the air quality near central China. Aerosol Air Qual Res 20

Publisher's note Springer Nature remains neutral with regard to jurisdictional claims in published maps and institutional affiliations. 